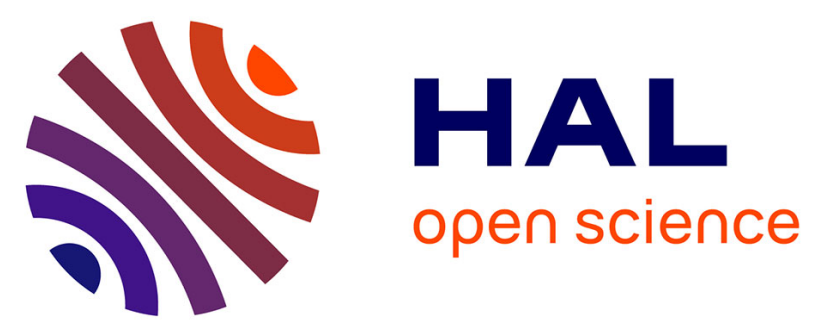

\title{
CHEMO-ENZYMATIC SYNTHESIS AND FREE RADICAL POLYMERIZATION OF RENEWABLE ACRYLATE MONOMERS FROM CELLULOSE-BASED LACTONES
}

Florian Diot-Néant, Enita Rastoder, Stephen A Miller, Florent Allais

\section{To cite this version:}

Florian Diot-Néant, Enita Rastoder, Stephen A Miller, Florent Allais. CHEMO-ENZYMATIC SYNTHESIS AND FREE RADICAL POLYMERIZATION OF RENEWABLE ACRYLATE MONOMERS FROM CELLULOSE-BASED LACTONES. ACS Sustainable Chemistry \& Engineering, 2018, 6 (12), pp.17284-17293. 10.1021/acssuschemeng.8b04707 . hal-02777141

\author{
HAL Id: hal-02777141 \\ https://hal.science/hal-02777141
}

Submitted on 4 Jun 2020

HAL is a multi-disciplinary open access archive for the deposit and dissemination of scientific research documents, whether they are published or not. The documents may come from teaching and research institutions in France or abroad, or from public or private research centers.
L'archive ouverte pluridisciplinaire HAL, est destinée au dépôt et à la diffusion de documents scientifiques de niveau recherche, publiés ou non, émanant des établissements d'enseignement et de recherche français ou étrangers, des laboratoires publics ou privés. 
CHEMO-ENZYMATIC SYNTHESIS AND FREE RADICAL POLYMERIZATION OF RENEWABLE ACRYLATE MONOMERS FROM CELLULOSE-BASED LACTONES

\title{
Florian Diot-Néant, ${ }^{\mathrm{a}, \mathrm{b}}$ Enita Rastoder, ${ }^{\mathrm{a}}$ Stephen A. Miller, ${ }^{*, a}$ and Florent Allais*b
}

a The George and Josephine Butler Laboratory for Polymer Research, Department of Chemistry, University of Florida, Gainesville,Florida 32611-7200, United States

b Chaire Agro-Biotechnologies Industrielles (ABI), AgroParisTech, CEBB, 3 rue des Rouges Terres, 51110

Pomacle, France

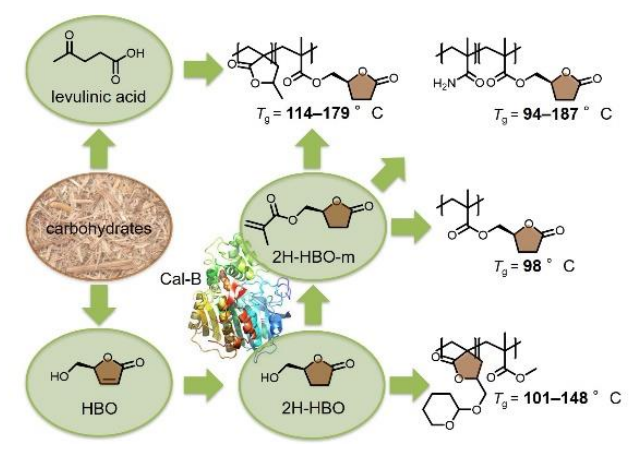

\begin{abstract}
A chemo-enzymatic pathway involving a Candida antarctica type B lipase was developed

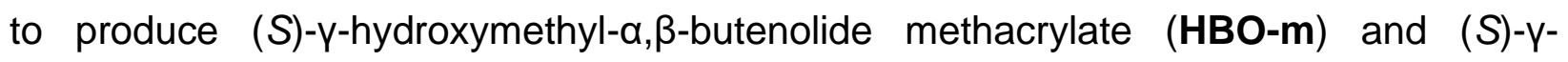

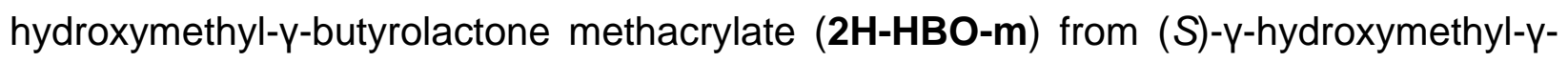
butyrolactone (HBO), a biobased molecule obtained from cellulose-derived levoglucosenone. The acrylated monomer was then copolymerized through a free radical process with methacrylamide and methylene- $y$-valerolactone, a green intermediate. Finally, methylene-tetrahydropyranyl (S)-y-hydroxymethyl-y-butyrolactone (M-THP-2HHBO), synthesized via a-methylenation of $\mathbf{2 H}-\mathbf{H B O}$, was copolymerized with methyl methacrylate to access copolyacrylates exhibiting high glass transition temperatures.
\end{abstract}

KEYWORDS: Levoglucosenone, HBO, Lipase biocatalysis, Functionalized (meth)acrylates, $\alpha-$ Methylenation, Biobased polymers, Polyacrylates 


\section{Background}

Over the last several decades, the growing production of materials ${ }^{1}$ and synthetic goods has raised severe concerns regarding pollution and the inevitable depletion of fossil-fuel resources. In that context, numerous investigations have been conducted in attempts to replace fossil-based products such as plastics. ${ }^{2}$ Exploration and progress of white technologies and green chemistry applied to biomass have been a major achievement to supplant non-sustainable molecules and materials. For instance, transformations of biomass into biobased platform chemicals by microorganisms and extractions of molecules of interest from biorenewable sources such as lignocellulose have substantially contributed to extend the database of renewable synthons.

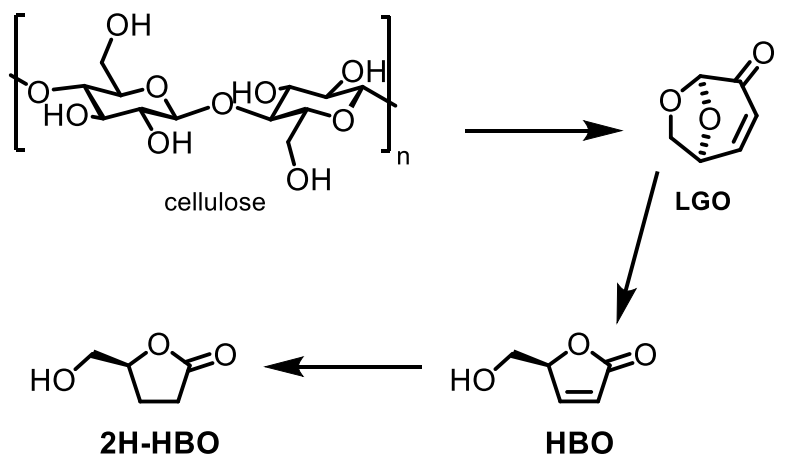

Scheme 1. Transformation of cellulose into $\mathrm{HBO}$ followed by hydrogenation to $\mathbf{2 H}-$ HBO.

Biobased 2,5-furanedicarboxylic acid ${ }^{3}$ has shown great potential to replace the terephthalic acid of poly(ethylene terephthalate) (PET), while sugar fermentation product lactic acid has already demonstrated commercial success with the well-known polymer poly(lactic acid) (PLA). Besides its slow decomposition in the environment, the low $T_{\mathrm{g}}$ value $\left(55^{\circ} \mathrm{C}\right)^{4}$ of PLA precludes its utilization at high temperature. ${ }^{5}$ Recently, Miller and 
co-workers proposed new polylactam esters ${ }^{6}$ made from ethanolamine and sugar-derived itaconic acid, one of the top twelve biorenewable molecules extolled by the DOE. ${ }^{7}$ It is worth noting that this polymer not only competes with PLA in terms of $T_{\mathrm{g}}$ but exhibits facile degradability back to monomers in neutral water over the course of one year.
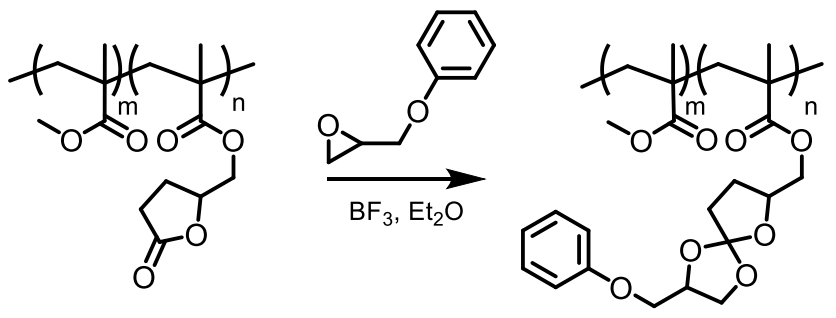

Scheme 2. Installation of spiro orthoester via post-polymerization reaction.

Among the expanding library of renewable molecules of interest that can be produced from lignocellulosic biomass such as levulinic $\operatorname{acid}^{8}$ and 3-hydroxy propionic acid (3-HP), ${ }^{9}(S)$ - $\gamma$-hydroxymethyl- $\alpha, \beta$-butenolide (HBO) (Scheme 1) has demonstrated its high potential. HBO was recently produced through two sustainable routes by Allais and co-workers from levoglucosenone (LGO), an interesting building block obtained from the flash pyrolysis of lignocellulosic biomass such as sawdust. ${ }^{10}$ The first route involved a lipase-mediated Baeyer-Villiger oxidation of LGO ${ }^{11}$ whereas the more recent route is a solvent-free and catalyst-free Baeyer-Villiger oxidation. ${ }^{12}$ The versatility of HBO has been employed to access not only valuable chiral building blocks such as chiral epoxides, but also end products such as enantiopure $(S)$-dairy lactone ${ }^{13}$ employed as a butter-like flavoring agent in food sectors such as the snack, ice cream, and bakery industries.

Although HBO is a valuable molecule used in fine chemistry (e.g., drugs, fine chemicals, flavoring agents), sparingly little research has targeted the valorization of this 
biobased synthon for the preparation of chiral monomers and subsequent polymers. In 1994, Zamzow and Höcker ${ }^{14}$ reported the synthesis of polymers with a spiro orthoester pendant group. The polymerization acrylate monomers bearing reactive lactones such as (S)-y-hydroxymethyl- $\alpha, \beta$-butyrolactone methacrylate $(2 \mathrm{H}-\mathrm{HBO}-\mathrm{m})$ was followed by installation of the desired spiro orthoester (Scheme 2). The adopted monomer synthesis required methacryloyl chloride, an inexpensive reagent that nonetheless results in substantial amounts of halogenated waste. Moreover, a base such as triethylamine or pyridine is essential for trapping the formed $\mathrm{HCl}$ and makes this process even less atomeconomical.

Recently, Saito and co-workers ${ }^{15}$ reported a new method to access $2 \mathrm{H}-\mathrm{HBO}-\mathrm{m}$ and its polymerization using different processes such as emulsion polymerization and RAFT polymerization. Although RAFT CTA agents are expensive, they afforded narrow dispersity polymers $(\Theta=1.06)$ with acceptable molecular weights of $9000 \mathrm{kDa}$. Copolymerizations of $\mathbf{2 H}-\mathbf{H B O}-\mathbf{m}$ with petroleum-based comonomers, such as styrene and butyl methacrylate, were successfully achieved through emulsion polymerization. The reported synthetic pathway has the main advantage to substitute methacryloyl chloride with methacrylic anhydride and to replace dichloromethane with ethyl acetate, a markedly greener solvent. ${ }^{16}$ Notwithstanding these improvements, this method presents several drawbacks, including the utilization of non-green organic bases: 4dimethylaminopyridine (DMAP, $1 \% \mathrm{~mol}$ ) and triethylamine (Et $3 \mathrm{~N}, 1$ equiv.), known to be noxious and waste-generating. While $\mathrm{Et}_{3} \mathrm{~N}$ salts are mainly removed through filtration, the work-up protocol with $\mathrm{NaHCO}_{3}$ does allow product purification. However, the methacrylic acid by-product and unreacted $\mathbf{2} \mathrm{H}-\mathbf{H B O}$ are mixed in the aqueous layer with salts. 
Additional steps must be performed to separate the aforementioned chemicals before reuse, greatly reducing the overall process efficiency. Consequently, a more environmentally-friendly synthetic strategy that would substantially reduce the waste is still needed.

Herein, we report a more sustainable approach (i.e., no halogenated species, no base) using the chemo-enzymatic catalysis ${ }^{17}$ of Candida antarctica type $B$ lipase (CALB, a.k.a. Novozyme $435^{\circledR}$ ) to access acrylates (S)-y-hydroxymethyl- $\alpha, \beta$-butenolide methacrylate (HBO-m) and its corresponding hydrogenated version $\mathbf{2 H}-\mathbf{H B O}-\mathbf{m}$, from $\mathrm{HBO}$ and $\mathbf{2 H}-\mathrm{HBO}$, respectively. The resulting monomers were then polymerized with comonomers in order to tune the thermal properties and the solubility of the resulting polymers. Moreover, a new type of monomer similar to methylene- $y$-valerolactone (MGVL) was synthesized from HBO and polymerized. 


\section{Experimental}

\section{Chemicals and regeants}

Levoglucosenone was graciously provided by the Circa Group. Lipase acrylic resin from Candida antarctica (Cal-B) was purchased from Sigma Aldrich. Hydrogen peroxide $30 \%$ (Fischer), propionic acid (Sigma Aldrich), butanoic acid (Sigma Aldrich), 2-butenoic acid (Sigma Aldrich), trans-2-pentenoic acid (Sigma Aldrich), 4-pentenoic acid (Sigma Aldrich), AIBN (Sigma Aldrich), V-65 (Sigma Aldrich), V-70 (Sigma Aldrich), methyl methacrylate stabilized (Fischer), methacryloyl chloride (Sigma Aldrich), methacrylic anhydride (Sigma Aldrich), methacrylamide 98\% (Alfa Aesar), triethylamine (Sigma Aldrich), $\quad$-valerolactone 99\% (Sigma Aldrich), ethyl formate 97\% (Sigma Aldrich), sodium hydride 60\% dispersion in mineral oil (Sigma Aldrich), paraformaldehyde 95\% (Sigma Aldrich), 3,4-dihydro-2H-pyrane (Sigma Aldrich), 10\% by weight palladium on

activated carbon (Acros), potassium carbonate (Fischer), sodium hydroxide (Fischer), para-toluenesulfonic acid monohydrate 98\% (Sigma Aldrich), were all used without further purification. NMR solvents including deuterated chloroform, deuterated methanol, and deuterated dimethyl sulfoxide were purchased from Cambridge Isotopes Laboratories. All the chemicals, unless noted otherwise, were used as received. The pyridinium paratoluenesulfonate was prepared from para-toluenesulfonic acid (1 equiv.) in pyridine (5 equiv.) and recrystallized from acetone.

\section{Characterization}

\section{Nuclear Magnetic Resonance (NMR) spectroscopy}

Proton nuclear magnetic resonance $\left({ }^{1} \mathrm{H} N \mathrm{NM}\right)$ and carbon nuclear magnetic resonance $\left({ }^{13} \mathrm{C}\right.$ NMR) were recorded employing an Inova $500 \mathrm{MHz}$ or a Varian Mercury $300 \mathrm{MHz}$ 
spectrometer. Chemical shifts are reported in parts per million (ppm) downfield relative to tetramethylsilane (TMS, $0.0 \mathrm{ppm})$. Coupling constants (J) are reported in Hertz $(\mathrm{Hz})$. Multiplicities are reported using the following abbreviations: $s$, singlet; $d$, doublet; $t$, triplet; q, quartet; m, multiplet; br, broad.

\section{Mass spectroscopy}

HRMS was recorded by the Mass Spectroscopy Research and Education Center (Department of Chemistry, University of Florida) on an Agilent 6220 Time-of-Flight (TOF) MS.

\section{Infra-Red (IR) spectroscopy}

Solid-state IR is recorded using a Perkin Elmer Spectrum One FT-IR. spectrophotometer. Thermogravimetric Analysis (TGA)

TGA was measured under nitrogen with a TGA Q5000 from TA Instruments. About 1-5 $\mathrm{mg}$ of each sample were cooled down to $0^{\circ} \mathrm{C}$ and held at that temperature for $5 \mathrm{~min}$. Then the samples were heated at $20^{\circ} \mathrm{C} / \mathrm{min}$ from 0 to $600{ }^{\circ} \mathrm{C}$. The reported value $\left(T_{\mathrm{d} 5 \%}\right)$ represents the temperature at which $5 \%$ of the mass is lost.

\section{Differential Scanning Calorimetry (DSC)}

DSC thermograms were obtained with a DSC Q1000 from TA instruments. Typically, 3-7 mg of sample were weighed and added to a sealed pan that passed through a heat-coolheat cycle at $10{ }^{\circ} \mathrm{C} / \mathrm{min}$. The temperature ranged from $40^{\circ} \mathrm{C}$ to the $T_{\mathrm{d} 5 \%}$ of the polymers. Gel Permeation Chromatography (GPC)

GPC was performed at $40^{\circ} \mathrm{C}$ using an Agilent Technologies 1260 Infinity Series liquid chromatography system with an internal differential refractive index detector, and two 
Waters Styragel HR-5E columns (7.8 mm i.d., $300 \mathrm{~mm}$ length, guard column $7.8 \mathrm{~mm}$ i.d., $25 \mathrm{~mm}$ length) using a solution of $0.1 \%$ potassium triflate (K(OTf)) in HPLC grade hexafluoroisopropanol (HFiP) as the mobile phase at a flow rate of $0.3 \mathrm{~mL} / \mathrm{min}$. Calibration was performed with narrow dispersity polymethyl methacrylate standards.

\section{Monomer synthesis}

\section{Synthesis of (S)-5-(hydroxymethyl)furan-2(5H)-one (HBO)}

Levoglucosenone (LGO, 1 equiv.) was dissolved in ethyl acetate $(C=1 \mathrm{M})$. A catalytic amount of CAL-B (10 w\%) was added to the reaction mixture, and then aqueous hydrogen peroxide ( 1.2 equiv. $30 \% \mathrm{w} / \mathrm{w}$ ) was added dropwise. The mixture was heated at $40{ }^{\circ} \mathrm{C}$ overnight. CAL-B was removed by filtration and the filtrate was concentrated to dryness. The resulting crude mixture was taken up in methanol ( $C=0.1 \mathrm{M}$ relative to $\mathrm{LGO})$. Concentrated hydrochloric acid (12 equiv. relative to LGO) was added at RT and the reaction mixture was stirred at $45^{\circ} \mathrm{C}$ until complete consumption of starting material, as monitored by TLC. The crude mixture was evaporated to dryness and was purified by silica gel chromatography (elution with $50 \%$ to $100 \%$ ethyl acetate in cyclohexane) to yield to pure $\mathrm{HBO}$ ( $75 \%$ yield).

An $30 \%$ aq. $\mathrm{H}_{2} \mathrm{O}_{2}$ solution (9.78 M, $0.81 \mathrm{~L}, 7.92$ mol, 1 equiv./LGO) was added dropwise over 3.5 hours under nitrogen to LGO (1 kg, $7.93 \mathrm{~mol})$ cooled down with an ice bath. After completion of the addition, the reaction was warmed to $50{ }^{\circ} \mathrm{C}$ and stirred for an extra 20 hours. Presence of $\mathrm{H}_{2} \mathrm{O}_{2}$ was evaluated with peroxide strips and, if any, the residual $\mathrm{H}_{2} \mathrm{O}_{2}$ was quenched using the methods described in the manuscript. The reaction mixture was 
then concentrated in vacuo and the residue was distilled of $\left(150{ }^{\circ} \mathrm{C} / 0.7-0.9 \mathrm{mbar}\right)$ to provide $\mathrm{HBO}$ as a clear oil that readily crystallizes.

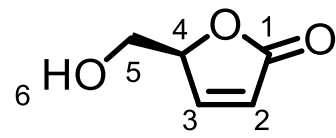

${ }^{1} \mathrm{H}$ NMR $\left(\mathrm{CDCl}_{3}, 300 \mathrm{MHz}\right): \delta_{\mathrm{H}} 1.93$ (br s, $1 \mathrm{H}, \mathrm{H}_{6}$ ), 3.89 (ddd, $2 \mathrm{H}, J=3.7,5.0$ and 12.2 $\left.\mathrm{Hz}, \mathrm{H}_{5}\right), 5.14\left(\mathrm{~m}, 1 \mathrm{H}, \mathrm{H}_{4}\right), 6.20\left(\mathrm{dd}, 1 \mathrm{H}, J=2.0\right.$ and $\left.5.7 \mathrm{~Hz}, \mathrm{H}_{2}\right), 7.46(\mathrm{dd}, 1 \mathrm{H}, J=1.6$ and $\left.5.7 \mathrm{~Hz}, \mathrm{H}_{3}\right) .{ }^{13} \mathrm{C} \mathrm{NMR}\left(\mathrm{CDCl}_{3}, 125 \mathrm{MHz}\right): \delta_{\mathrm{c}} 62.1\left(\mathrm{C}_{5}\right), 84.4\left(\mathrm{C}_{4}\right), 122.8\left(\mathrm{C}_{2}\right), 154.1\left(\mathrm{C}_{3}\right)$, $173.7\left(\mathrm{C}_{1}\right)$.

\section{Synthesis of (S)-5-(hydroxymethyl)dihydrofuran-2(3H)-one (2H-HBO)}

To a solution of $7.293 \mathrm{~g}(63.9 \mathrm{mmol})$ of $\mathrm{HBO}$ in $90 \mathrm{~mL}$ of ethyl acetate were added 1.496 $\mathrm{g}$ of $\mathrm{Pd} / \mathrm{C}(10 \% \mathrm{w} / \mathrm{w})$. The system was degassed 3 times and was kept under dihydrogen (20 psi). The suspension was stirred overnight. The $\mathrm{Pd} / \mathrm{C}$ was then removed by filtration through celite and the filtrate was concentrated to dryness. The crude product was used without further purification.

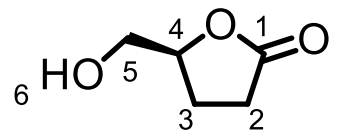

${ }^{1} \mathrm{H}$ NMR $\left(\mathrm{CDCl}_{3}, 300 \mathrm{MHz}\right): \delta \mathrm{H} 1.95\left(\mathrm{~m}, 2 \mathrm{H}, \mathrm{H}_{3}\right), 2.32\left(\mathrm{~m}, 2 \mathrm{H}, \mathrm{H}_{2}\right), 3.49(\mathrm{dd}, 2 \mathrm{H}, J=3.0$ and $\left.15.0 \mathrm{~Hz}, \mathrm{H}_{5}\right), 4.01$ (br s, $\left.1 \mathrm{H}, \mathrm{H}_{6}\right), 4.40\left(\mathrm{~m}, 1 \mathrm{H}, \mathrm{H}_{4}\right) .{ }^{13} \mathrm{C} \mathrm{NMR}\left(\mathrm{CDCl}_{3}, 75 \mathrm{MHz}\right): \delta \mathrm{c}$ $23.0\left(\mathrm{C}_{3}\right), 28.5\left(\mathrm{C}_{2}\right), 63.6\left(\mathrm{C}_{5}\right), 81.1\left(\mathrm{C}_{4}\right), 178.5\left(\mathrm{C}_{1}\right)$.

\section{Study of chemo-enzymatic reaction}

In a typical experiment, 3 equivalents of propionic acid were added to a solution of 500 $\mathrm{mg}(4.4 \mathrm{mmol}, 1$ equiv.) of $\mathrm{HBO}$ in $4.4 \mathrm{~mL}$ of toluene $(C=1 \mathrm{M})$. The mixture was heated 
up to $70^{\circ} \mathrm{C}$ and was stirred during $24 \mathrm{~h}$. Then, the CAL-B was filtered out and the filtrate was concentrated. The conversion was then evaluated by ${ }^{1} \mathrm{H}$ NMR of the crude reaction material.

\section{Synthesis of (S)-5-(methyl)dihydrofuran-2(3H)-one methacrylate (2H-HBO-m)}

In a typical experiment, a catalytic amount of CAL-B (10 w\% relative to the $2 \mathrm{H}-\mathrm{HBO}$ ) was added to a solution of $1.0 \mathrm{~g}$ (8.6 mmol, 1 equiv.) of $2 \mathrm{H}-\mathrm{HBO}$ in $23 \mathrm{~mL}(215.9 \mathrm{mmol}, 25$ equiv.) of methyl methacrylate. The system was heated up to $70{ }^{\circ} \mathrm{C}$ and stirred for $24 \mathrm{~h}$. Then, the supported enzyme was filtered out and the filtrate was concentrated to dryness. The crude product was taken up in $20 \mathrm{~mL}$ of dichloromethane and was washed thrice with $20 \mathrm{~mL}$ of de-ionized water. The organic layer was dried over anhydrous $\mathrm{MgSO}_{4}$ and concentrated to dryness. Quick filtration over silica gel was then performed and the pure product was obtained (62\% yield).

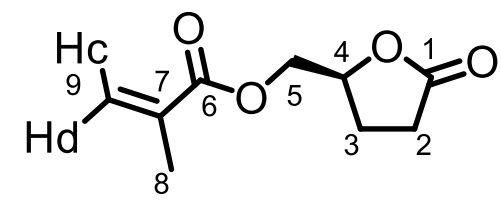

${ }^{1} \mathrm{H} \operatorname{NMR}\left(\mathrm{CDCl}_{3}, 300 \mathrm{MHz}\right): \delta_{\mathrm{H}} 1.89\left(\mathrm{~s}, 3 \mathrm{H}, \mathrm{H}_{8}\right), 2.26\left(\mathrm{~m}, 2 \mathrm{H}, \mathrm{H}_{3}\right), 2.60\left(\mathrm{~m}, 2 \mathrm{H}, \mathrm{H}_{2}\right), 4.34$ (dd, $2 \mathrm{H}, J=3.0$ and $\left.12.0 \mathrm{~Hz}, \mathrm{H}_{5}\right), 4.82\left(\mathrm{~m}, 1 \mathrm{H}, \mathrm{H}_{4}\right), 5.65\left(\mathrm{~m}, 1 \mathrm{H}, \mathrm{H}_{9 c}\right), 6.16\left(\mathrm{~m}, 1 \mathrm{H}, \mathrm{H}_{9 \mathrm{~d}}\right)$. ${ }^{13} \mathrm{C}$ NMR $\left(\mathrm{CDCl}_{3}, 75 \mathrm{MHz}\right): \delta_{\mathrm{C}} 18.1\left(\mathrm{C}_{8}\right), 24.7\left(\mathrm{C}_{3}\right), 28.0\left(\mathrm{C}_{2}\right), 65.5\left(\mathrm{C}_{5}\right), 77.3\left(\mathrm{C}_{4}\right), 126.3$ $\left(\mathrm{C}_{7}\right), 135.5\left(\mathrm{C}_{9}\right), 166.9\left(\mathrm{C}_{6}\right), 176.7\left(\mathrm{C}_{1}\right)$.

Synthesis of (S)-5-(methyl)furan-2(3H)-one methacrylate (HBO-m)

The same procedure as for $\mathbf{2 H}-\mathrm{HBO}-\mathrm{m}$ was used. 


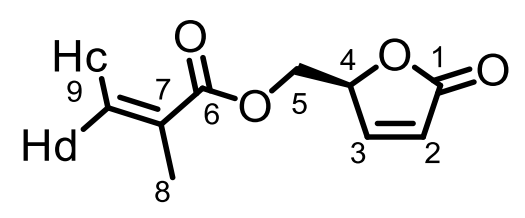

${ }^{1} \mathrm{H} \mathrm{NMR}\left(\mathrm{CDCl}_{3}, 500 \mathrm{MHz}\right): \delta_{\mathrm{H}} 1.86\left(\mathrm{~s}, 3 \mathrm{H}, \mathrm{H}_{8}\right), 4.40\left(\mathrm{dd}, 2 \mathrm{H}, J=5.0\right.$ and $\left.15 \mathrm{~Hz}, \mathrm{H}_{5}\right), 5.27$ $\left(\mathrm{m}, 1 \mathrm{H}, \mathrm{H}_{4}\right), 5.56\left(\mathrm{~m}, 1 \mathrm{H}, \mathrm{H}_{9 \mathrm{c}}\right), 6.04\left(\mathrm{~m}, 1 \mathrm{H}, \mathrm{H}_{9 \mathrm{~d}}\right), 6.16\left(\mathrm{~d}, 1 \mathrm{H}, J=5.8 \mathrm{~Hz}, \mathrm{H}_{2}\right), 7.47(\mathrm{~d}, 1 \mathrm{H}$, $\left.J=5.8 \mathrm{~Hz}, \mathrm{H}_{3}\right) .{ }^{13} \mathrm{C} \mathrm{NMR}\left(\mathrm{CDCl}_{3}, 125 \mathrm{MHz}\right): \delta \mathrm{c} 18.1\left(\mathrm{C}_{8}\right), 62.6\left(\mathrm{C}_{5}\right), 80.9\left(\mathrm{C}_{4}\right), 123.0$ $\left(\mathrm{C}_{2}\right), 126.7\left(\mathrm{C}_{7}\right), 135.3\left(\mathrm{C}_{9}\right), 152.8\left(\mathrm{C}_{3}\right), 166.6\left(\mathrm{C}_{6}\right), 172.3\left(\mathrm{C}_{1}\right)$. After purification by flash chromatography, the following spectra were obtained. ${ }^{1} \mathrm{H} \mathrm{NMR}\left(\mathrm{CDCl}_{3}, 300 \mathrm{MHz}\right): \delta \mathrm{H}$ $1.84\left(\mathrm{~s}, 3 \mathrm{H}, \mathrm{H}_{8}\right), 4.38\left(\mathrm{dd}, 2 \mathrm{H}, J=3.0\right.$ and $\left.12.0 \mathrm{~Hz}, \mathrm{H}_{5}\right), 5.24\left(\mathrm{~m}, 1 \mathrm{H}, \mathrm{H}_{4}\right), 5.54(\mathrm{~m}, 1 \mathrm{H}$, $\left.\mathrm{H}_{9 c}\right), 6.03\left(\mathrm{~m}, 1 \mathrm{H}, \mathrm{H}_{9 \mathrm{~d}}\right), 6.14\left(\mathrm{dd}, 1 \mathrm{H}, J=2.1\right.$ and $\left.5.8 \mathrm{~Hz}, \mathrm{H}_{2}\right), 7.44(\mathrm{dd}, 1 \mathrm{H}, J=1.6$ and $\left.5.8 \mathrm{~Hz}, \mathrm{H}_{3}\right) .{ }^{13} \mathrm{C} \mathrm{NMR}\left(\mathrm{CDCl}_{3}, 75 \mathrm{MHz}\right): \delta \mathrm{c} 18.1\left(\mathrm{C}_{8}\right), 62.6\left(\mathrm{C}_{5}\right), 80.9\left(\mathrm{C}_{4}\right), 123.1\left(\mathrm{C}_{2}\right)$, $126.8\left(\mathrm{C}_{7}\right), 135.3\left(\mathrm{C}_{9}\right), 152.8\left(\mathrm{C}_{3}\right), 166.6\left(\mathrm{C}_{6}\right), 172.3\left(\mathrm{C}_{1}\right)$.

\section{Synthesis of (S)-5-(hydroxymethyl)furan-2(5H)-one acetate}

To a solution of $2.985 \mathrm{~g}$ (26.1 mmol, 1 equiv.) of $\mathrm{HBO}$ in $130 \mathrm{~mL}$ of AcOEt was added 10 w\% of CAL-B (relative to HBO). The system was heated at $70{ }^{\circ} \mathrm{C}$ for 1 day. Then the CAL-B was filtered out and the filtrate was concentrated to dryness. The crude product was taken up in $20 \mathrm{~mL}$ of dichloromethane and washed twice with distilled water and once with brine. The organic layer was dried over anhydrous $\mathrm{MgSO}_{4}$ and concentrated to dryness. The crude product was purified via silica gel column chromatography (elution $80 \%$ of hexane to $60 \%$ of hexane in ethyl acetate) to give $3.14 \mathrm{~g}$ of a colorless oil $(77 \%$ yield).

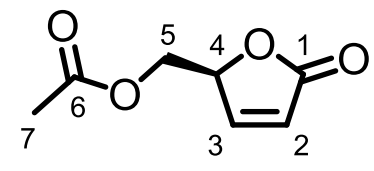


${ }^{1} \mathrm{H} \mathrm{NMR}\left(\mathrm{CDCl}_{3}, 300 \mathrm{MHz}\right): \delta_{\mathrm{H}} 2.02\left(\mathrm{~s}, 3 \mathrm{H}, \mathrm{H}_{7}\right), 4.31$ (dd, $2 \mathrm{H}, J=3.0$ and $\left.6.0 \mathrm{~Hz}, \mathrm{H}_{5}\right)$, $5.22\left(\mathrm{~m}, 1 \mathrm{H}, \mathrm{H}_{4}\right), 6.18\left(\mathrm{~d}, 1 \mathrm{H}, J=3.0 \mathrm{~Hz}, \mathrm{H}_{2}\right), 7.45\left(\mathrm{~d}, 1 \mathrm{H}, J=3.0 \mathrm{~Hz}, \mathrm{H}_{3}\right) .{ }^{13} \mathrm{C} \mathrm{NMR}$ $\left(\mathrm{CDCl}_{3}, 75 \mathrm{MHz}\right): \delta_{\mathrm{c}} 20.5\left(\mathrm{C}_{7}\right), 62.5\left(\mathrm{C}_{5}\right), 80.8\left(\mathrm{C}_{4}\right), 123.2\left(\mathrm{C}_{2}\right), 152.6\left(\mathrm{C}_{3}\right), 170.5\left(\mathrm{C}_{6}\right)$, $172.3\left(\mathrm{C}_{1}\right)$.

\section{Synthesis of methylene- $\mathrm{y}$-valerolactone}

To a stirred solution of $\mathrm{NaH}$ (60\% dispersion in mineral oil, 1 equiv.) in dry diethyl ether, $600 \mu \mathrm{L}$ of ethanol were added under $\mathrm{N}_{2}$. Then a mixture of $10 \mathrm{~g}$ (100 mmol, 1 equiv.) of $\mathrm{Y}$-valerolactone and $8 \mathrm{~mL}$ (100 mmol, 1 equiv.) of ethyl formate was added dropwise at 0 ${ }^{\circ} \mathrm{C}$. The system was allowed to return to room temperature and was stirred during $1 \mathrm{~h}$. Then, the precipitate was filtered out to afford the salt in quantitative yield. The salt was added to $40 \mathrm{~mL}$ dry THF with 4.5 equiv. of paraformaldehyde. The system was heated to reflux during $3 \mathrm{~h}$ in order to crack the paraformaldehyde into formaldehyde. After $3 \mathrm{~h}$, the mixture was concentrated to dryness and the crude product was taken up in $60 \mathrm{~mL}$ of diethyl ether and was washed twice with a saturated solution of potassium carbonate. The organic layers were combined, dried over anhydrous $\mathrm{MgSO}_{4}$ and concentrated. The crude product was purified over silica gel column chromatography (elution with $100 \%$ hexane to $50 \%$ hexane in ethyl acetate) to give a pure product in $47 \%$ yield. It is worth noting that the pure product starts to polymerize during evaporation of the solvent.

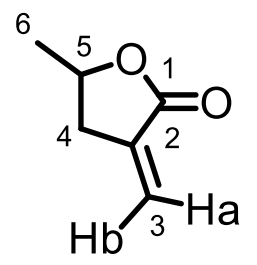


${ }^{1} \mathrm{H} \mathrm{NMR}\left(\mathrm{CDCl}_{3}, 300 \mathrm{MHz}\right): \delta_{\mathrm{H}} 1.41\left(\mathrm{~d}, 3 \mathrm{H}, J=6.0 \mathrm{~Hz}, \mathrm{H}_{6}\right), 2.83\left(\mathrm{~m}, 2 \mathrm{H}, \mathrm{H}_{4}\right), 4.64(\mathrm{~m}, 1 \mathrm{H}$, $\left.\mathrm{H}_{5}\right), 5.62\left(\mathrm{t}, 1 \mathrm{H}, J=3.0 \mathrm{~Hz}, \mathrm{H}_{3 \mathrm{a}}\right), 6.21\left(\mathrm{t}, 1 \mathrm{H}, J=3.0 \mathrm{~Hz}, \mathrm{H}_{3 \mathrm{~b}}\right) .{ }^{13} \mathrm{C} \mathrm{NMR}\left(\mathrm{CDCl}_{3}, 75 \mathrm{MHz}\right)$ : $\delta_{\mathrm{c}} 21.8\left(\mathrm{C}_{6}\right), 35.0\left(\mathrm{C}_{4}\right), 73.9\left(\mathrm{C}_{5}\right), 121.7\left(\mathrm{C}_{2}\right), 135.0\left(\mathrm{C}_{3}\right), 170.2\left(\mathrm{C}_{1}\right)$.

\section{Synthesis of (4R)-dihydro-5-(tetrahydropyranyl) hydroxy- methyl-2(3H)-furanone} (THP-2H-HBO)

To a solution of $4.04 \mathrm{~g}$ (34.8 mmol, 1 equiv.) of $2 \mathrm{H}-\mathrm{HBO}$ in $40 \mathrm{~mL}$ of dichloromethane was added $911 \mathrm{mg}$ of pyridinium $p$-toluenesulfonate and $5.9 \mathrm{~mL}$ (64.7 mmol, 1.9 equiv.) of 3,4-dihydro- $2 \mathrm{H}$-pyran at $0{ }^{\circ} \mathrm{C}$. After addition, the system was allowed to stir at room temperature overnight. The resulting mixture was purified via silica gel column chromatography (elution $90 \%$ of hexane to $50 \%$ of hexane in ethyl acetate) to lead to a pure product in quantitative yield.

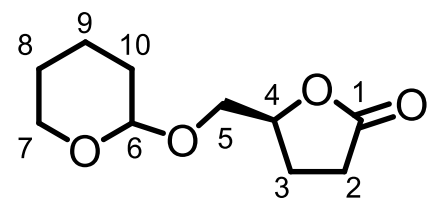

${ }^{1} \mathrm{H} \operatorname{NMR}\left(\mathrm{CDCl}_{3}, 300 \mathrm{MHz}\right): \delta_{\mathrm{H}} 1.53\left(\mathrm{~m}, 4 \mathrm{H}, \mathrm{H}_{8,9}\right), 1.67\left(\mathrm{~m}, 2 \mathrm{H}, \mathrm{H}_{10}\right), 2.18\left(\mathrm{~m}, 2 \mathrm{H}, \mathrm{H}_{3}\right)$, $2.54\left(\mathrm{~m}, 2 \mathrm{H}, \mathrm{H}_{2}\right) 3.70\left(\mathrm{~m}, 4 \mathrm{H}, \mathrm{H}_{5,7}\right), 4.63\left(\mathrm{~m}, 2 \mathrm{H}, \mathrm{H}_{4,6}\right) .{ }^{13} \mathrm{C} \mathrm{NMR}\left(\mathrm{CDCl}_{3}, 75 \mathrm{MHz}\right): \delta \mathrm{c}$ 18.9, 19.3 $\left(\mathrm{C}_{9}\right), 24.1\left(\mathrm{C}_{2}\right), 25.3\left(\mathrm{C}_{8}\right), 28.5\left(\mathrm{C}_{3}\right), 30.3\left(\mathrm{C}_{10}\right)$, 61.7, $62.3\left(\mathrm{C}_{7}\right)$, 68.8, $69.0\left(\mathrm{C}_{5}\right)$, 78.7, $79.0\left(\mathrm{C}_{4}\right), 98.5,99.2\left(\mathrm{C}_{6}\right), 177.3,177.5\left(\mathrm{C}_{1}\right)$. Diastereoisomerism gives two peaks for some carbon atoms.

Synthesis of (4R)-dihydro-5-(tetrahydropyranyl)hydroxy-methyl-3-methylene2(3H)-furanone (M-THP-2H-HBO)

To a suspension of $\mathrm{NaH}$ (60\% dispersion in mineral oil, 1 equiv.) in $45 \mathrm{~mL}$ of dry diethyl ether, $180 \mu \mathrm{L}$ of ethanol were added under $\mathrm{N}_{2}$. Then a mixture of $6.004 \mathrm{~g}(30 \mathrm{mmol}, 1$ 
equiv.) of THP-2H-HBO and of $2.4 \mathrm{~mL}$ (30 mmol, 1 equiv.) of ethyl formate was added dropwise at $0{ }^{\circ} \mathrm{C}$. The mixture was then stirred at room temperature during $30 \mathrm{~min}$. The precipitate was filtered out leading to the salt in a yield of $83 \% .3 .045 \mathrm{~g}$ of the salt were suspended in $20 \mathrm{~mL}$ of dry THF with 5 equiv. of paraformaldehyde. The mixture was refluxed for $2 \mathrm{~h}$ and then was filtered to eliminate unreacted paraformaldehyde. The solution was washed twice with a saturated solution of sodium carbonate. The organic layer was dried over anhydrous $\mathrm{MgSO}_{4}$ and concentrated to dryness. The crude product was purified over silica gel column chromatography (elution $90 \%$ hexane to $50 \%$ hexane in ethyl acetate) to give the pure liquid in $62 \%$ yield. It is worth noting that the pure product starts to self-polymerize during the concentration.

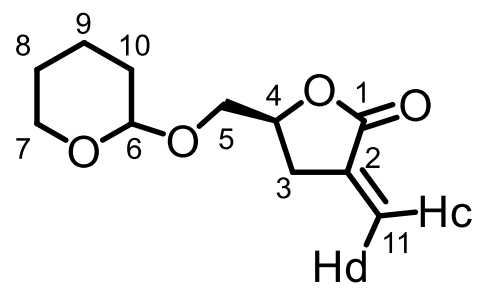

${ }^{1} \mathrm{H} \operatorname{NMR}\left(\mathrm{CDCl}_{3}, 300 \mathrm{MHz}\right): \delta_{\mathrm{H}} 1.50\left(\mathrm{~m}, 4 \mathrm{H}, \mathrm{H}_{8,9}\right), 1.70\left(\mathrm{~m}, 2 \mathrm{H}, \mathrm{H}_{10}\right), 2.89\left(\mathrm{~m}, 2 \mathrm{H}, \mathrm{H}_{3}\right)$, $3.69\left(\mathrm{~m}, 4 \mathrm{H}, \mathrm{H}_{5,7}\right), 4.60\left(\mathrm{t}, 0.51 \mathrm{H}, J=1.9 \mathrm{~Hz}, \mathrm{H}_{6}\right)$ and its diastereomeric peak at $4.65(\mathrm{t}$, $\left.0.56 \mathrm{H}, J=1.9 \mathrm{~Hz}, \mathrm{H}_{6}\right), 4.70\left(\mathrm{~m}, 1 \mathrm{H}, \mathrm{H}_{4}\right), 5.62\left(\mathrm{~m}, 1 \mathrm{H}, \mathrm{H}_{11 \mathrm{c}}\right), 6.20\left(\mathrm{~m}, 1 \mathrm{H}, \mathrm{H}_{11 \mathrm{~d}}\right) .{ }^{13} \mathrm{C} N M R$ $\left(\mathrm{CDCl}_{3}, 75 \mathrm{MHz}\right): \delta_{c} 18.9,19.2\left(\mathrm{C}_{9}\right), 25.3\left(\mathrm{C}_{8}\right), 29.7\left(\mathrm{C}_{3}\right), 30.3\left(\mathrm{C}_{10}\right)$, 61.8, 62.3 $\left(\mathrm{C}_{7}\right)$, 68.5, $68.6\left(\mathrm{C}_{5}\right), 75.5,75.7\left(\mathrm{C}_{4}\right), 98.6,99.2\left(\mathrm{C}_{6}\right), 121.5,121.7\left(\mathrm{C}_{2}\right), 134.3,134.5\left(\mathrm{C}_{11}\right), 170.1$, $170.3\left(\mathrm{C}_{1}\right)$. Diastereoisomerism gives two peaks for some carbon atoms. HRMS (TOF MS, ESI): $\mathrm{m} / \mathrm{z}$ calcd for $\mathrm{C}_{11} \mathrm{H}_{16} \mathrm{O}_{4} \mathrm{Na}$ : 235.0946; found: 235.0940 


\section{Polymerizations}

\section{Homopolymerization of (S)-5-(methyl)dihydrofuran-2(3H)-one methacrylate (poly 2H-HBO-m)}

In a typical experiment, $500 \mathrm{mg}$ of monomer were solubilized in toluene $(C=1 \mathrm{M})$; then 1 mol\% of AIBN was added. The system was purged 3 times (vacuum-nitrogen cycles) on a Schlenk line. The solution was stirred under $\mathrm{N}_{2}$ for $30 \mathrm{~min}$ and was then heated to 75 ${ }^{\circ} \mathrm{C}$ with a pre-heated oil bath. The polymerization was stopped after 90 minutes by exposure to air. The polymer was then precipitated by the addition of hexane.

\section{Copolymerization of (S)-5-(methyl)dihydrofuran-2(3H)-one methacrylate with methacrylamide (poly(2H-HBO-m-co-MAA))}

In a typical experiment, $250 \mathrm{mg}$ of $\mathbf{2 H}-\mathrm{HBO}-\mathrm{m}$ and $116 \mathrm{mg}$ of MAA $(50 \%$ MAA feed fraction) were dissolved $2.5 \mathrm{~mL}$ of DMF; then $1 \mathrm{~mol} \%$ (relative to the total molar quantity) of AIBN was added. The system was purged 3 times (vacuum-nitrogen cycles) on a Schlenk line. The solution was stirred under $\mathrm{N}_{2}$ for $30 \mathrm{~min}$ and was then heated to $75{ }^{\circ} \mathrm{C}$ with a pre-heated oil bath. The polymerization was stopped after 90 minutes by exposure to air. The polymer was then precipitated by the addition of methanol, resolubilized in hot DMSO and purified again by precipitation via $\mathrm{MeOH}$ addition.

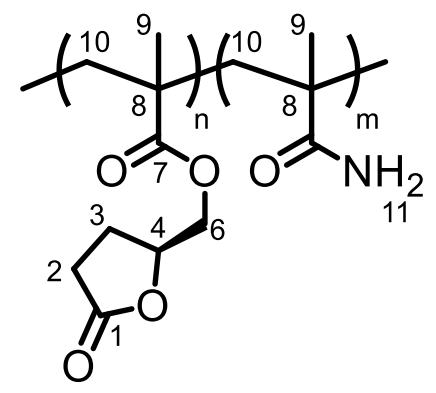


${ }^{1} \mathrm{H}$ NMR (DMSO, $\left.500 \mathrm{MHz}\right): \delta \mathrm{H} 0.87(\mathrm{~m}, 4.16 \mathrm{H}, \mathrm{H} 9), 1.78\left(\mathrm{~m}, 3.13 \mathrm{H}, \mathrm{H}_{10}\right), 2.43(\mathrm{~m}, 3.84 \mathrm{H}$, $\left.\mathrm{H}_{2,3}\right), 4.07\left(\mathrm{~m}, 1.80 \mathrm{H}, \mathrm{H}_{6}\right), 4.76\left(\mathrm{~m}, 1.01 \mathrm{H}, \mathrm{H}_{4}\right), 7.04\left(\mathrm{~m}, 0.76 \mathrm{H}, \mathrm{H}_{11}\right)$.

Copolymerization of (S)-5-(methyl)dihydrofuran-2(3H)-one methacrylate with methylene- $\mathrm{y}$-valerolactone (poly(2H-HBO-m-co-MGVL))

In a typical experiment, $250 \mathrm{mg}$ of $\mathbf{2 H}-\mathrm{HBO}-\mathrm{m}$ and $112 \mathrm{mg}$ of MGVL (50\% MGVL feed fraction) were dissolved in $2.7 \mathrm{~mL}$ of toluene; then $1 \mathrm{~mol} \%$ (relative to the total molar quantity) of AIBN was added. The system was purged 3 times (vacuum-nitrogen cycles) on a Schlenk line. The solution was stirred under $\mathrm{N}_{2}$ for $30 \mathrm{~min}$ and was then heated to $75^{\circ} \mathrm{C}$ with a pre-heated oil bath. The polymerization was stopped after 90 minutes by exposure to air. The polymer was then precipitated by the addition of $\mathrm{MeOH}$, resolubilized in hot $\mathrm{CHCl}_{3}$ and purified again by precipitation via $\mathrm{MeOH}$ addition.

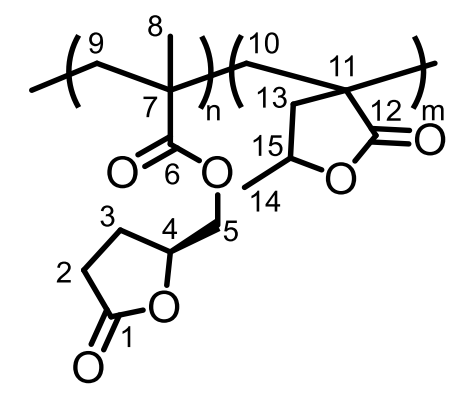

${ }^{1} \mathrm{H} \mathrm{NMR}\left(\mathrm{CDCl}_{3}, 500 \mathrm{MHz}\right): \delta_{\mathrm{H}} 1.03\left(\mathrm{br}, 2.59 \mathrm{H}, \mathrm{H}_{8}\right), 1.45\left(\mathrm{br}, 4.6 \mathrm{H}, \mathrm{H}_{14,8}\right), 1.70(\mathrm{br}, 2.41 \mathrm{H}$,

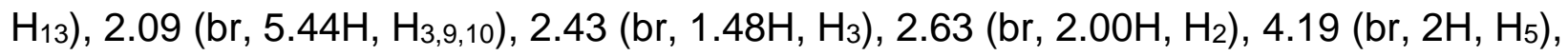
$4.64\left(\mathrm{br}, 1 \mathrm{H}, \mathrm{H}_{15}\right), 4.83\left(\mathrm{br}, 1 \mathrm{H}, \mathrm{H}_{4}\right)$.

Copolymerization of M-THP-2H-HBO with methyl methacrylate (MMA) (poly(MTHP-2H-HBO-co-MMA))

In a typical experiment, $253 \mathrm{mg}$ of M-THP-2H-HBO and $473 \mathrm{mg}$ of MMA (80\% MMA feed fraction) were dissolved in $6 \mathrm{~mL}$ of toluene; then $1 \mathrm{~mol} \%$ (relative to the total molar 
quantity) of AIBN was added. The system was purged 3 times (vacuum- nitrogen cycles) on a Schlenk line. The solution was stirred under $\mathrm{N}_{2}$ for $30 \mathrm{~min}$ and was then heated to $75{ }^{\circ} \mathrm{C}$ with a pre-heated oil bath. The polymerization was stopped after 90 minutes by exposure to air. The polymer was then precipitated by addition of hexane, resolubilized in hot $\mathrm{CHCl}_{3}$ and purified again by precipitation via hexane addition.

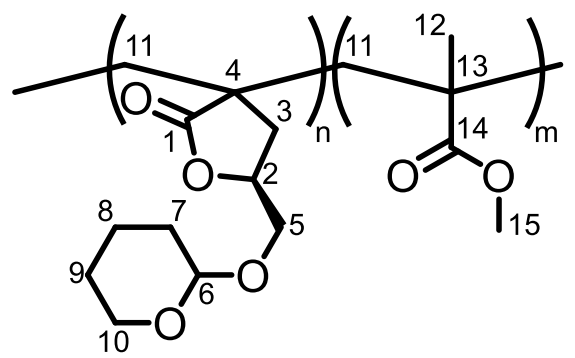

${ }^{1} \mathrm{H} \mathrm{NMR}\left(\mathrm{CDCl}_{3}, 500 \mathrm{MHz}\right): \delta_{\mathrm{H}} 1.54\left(\mathrm{br}, 12.45 \mathrm{H}, \mathrm{H}_{7,8,9,11,12),} 2.26\left(\mathrm{br}, 1.66 \mathrm{H}, \mathrm{H}_{3}\right), 3.52(\mathrm{br}\right.$, 1.61H, $\left.\mathrm{H}_{5,10}\right), 3.65\left(\mathrm{br}, 2.65 \mathrm{H}, \mathrm{H}_{15}\right), 3.82\left(\mathrm{br}, 1.78 \mathrm{H}, \mathrm{H}_{5,10}\right), 4.03\left(\mathrm{br}, 0.26 \mathrm{H}, \mathrm{H}_{5}\right), 4.68(\mathrm{br}$, $\left.2 \mathrm{H}, \mathrm{H}_{2,6}\right)$. 


\section{Results and discussions}

Lipases are biocatalysts known to perform hydrolysis of fatty acid esters in aqueous media but esterification or transesterification can be achieved by changing the nature of the solvent. Indeed, utilization of an organic solvent such as toluene rather than water has successfully allowed transesterifications in the presence of an excess (3 equiv.) of exogenous ester or alcohol. ${ }^{18}$ It is noteworthy to mention that supported enzyme attached to acrylic resin for example - can be used over a wider temperature range. ${ }^{19}$ In addition, supported CAL-B is easily filtered out and potentially reused. Consequently, transesterification of methyl methacrylate (MMA) with $\mathrm{HBO}$ in the presence of $10 \mathrm{w} \%$ CAL-B was performed in toluene at $70^{\circ} \mathrm{C}$. Unfortunately, no conversion was observed after 24 hours of reaction. Having already and successfully employed HBO in chemoenzymatic acylations, we identified MMA as a potential inhibitor of the reaction. Indeed, either the shape of MMA or its inherent conjugation (making the carbonyl less electrophilic) could prohibit its coordination into the active site of the biocatalyst and could explain the failure of CAL-B to conduct the reaction.

In an attempt to challenge our assumptions, several experiments employing either acids or unsaturated acids have been performed and the results are reported in Table 1. Entry 2 shows that the chemo-enzymatic transesterification between $\mathrm{HBO}$ and propionic acid only results in traces of product. One additional carbon in the backbone of the substrate (Table 1, Entry 3) allows the transesterification with modest conversion (37\%). When butanoic acid was replaced with 2-butenoic acid (Table 1, Entry 4), its unsaturated and conjugated analogue, the conversion dropped to zero. Plausibly, the resonance/conjugation drastically lowers the electrophilic character of the carbonyl, 
Table 1. Esterification of HBO with different acyl substrates in the presence of CAL-B. ${ }^{a}$

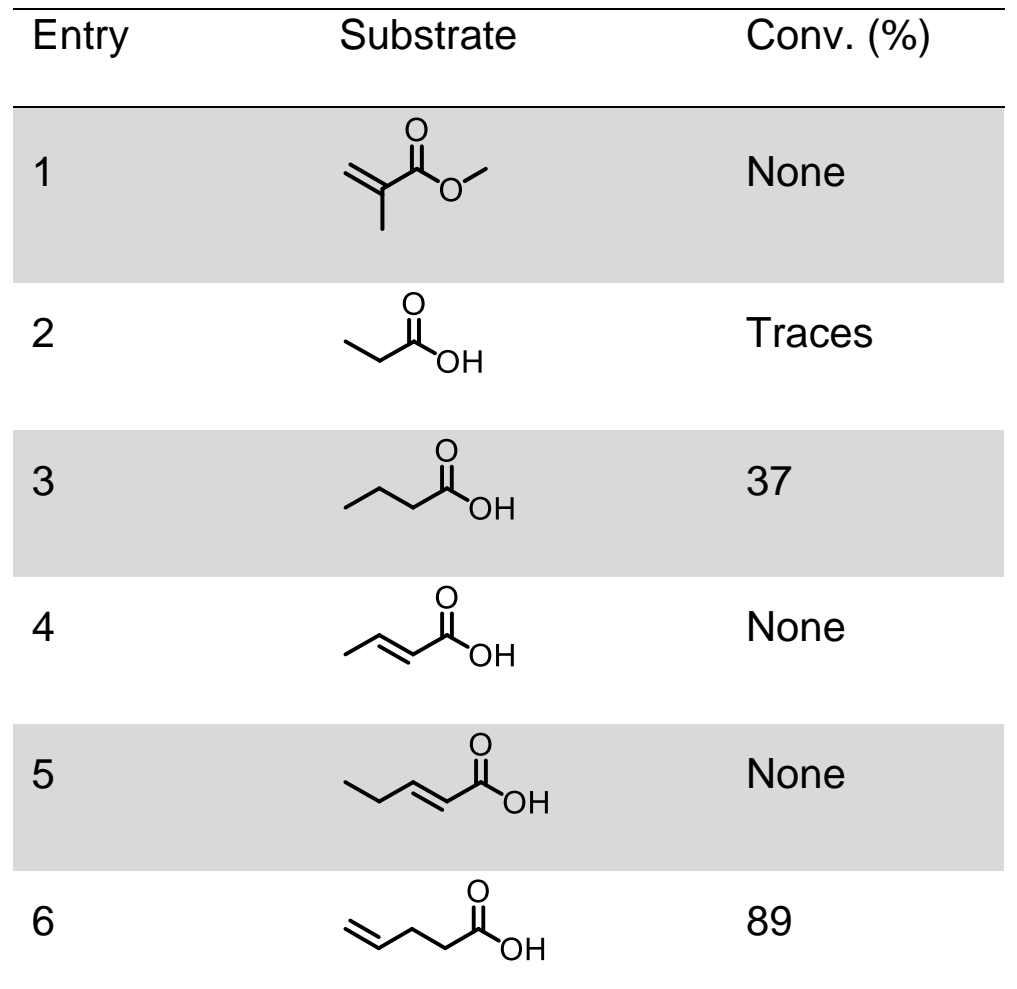

${ }^{a}$ Conditions: 3 equiv. of substrate; $10 \mathrm{w} \%$ of CAL-B; HBO $1 \mathrm{M}$ in toluene; $70^{\circ} \mathrm{C}, 1$ day.

hindering any nucleophilic attack. Finally, an attempt with a non-conjugated, unsaturated substrate (Table 1, Entry 6) gave an excellent conversion of $89 \%$, suggesting the conclusion that both the conjugation and the shape of MMA prevent the chemo-enzymatic reaction under these specific conditions.

In 1996, Rüsch gen. Klaas and co-workers ${ }^{20}$ reported the bio-catalyzed transesterification of unsaturated fatty alcohols with methyl methacrylate in the presence

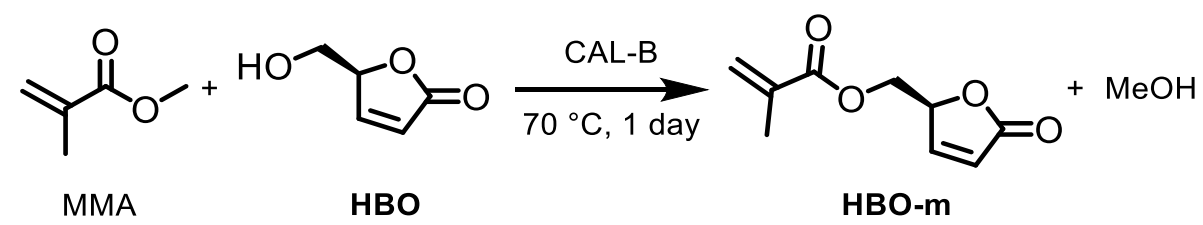

Scheme 3. Synthesis of HBO-m through chemo-enzymatic transesterification. 
of lipase. The reaction did occur in organic solvents such as toluene and tetrahydrofuran (THF), but the yield did not exceed $40 \%$. Although a rather high loading of CAL-B was employed (at least $30 \mathrm{w} \%$, triple the usual loading), the reaction proceeded at a moderate temperature of $30{ }^{\circ} \mathrm{C}$. In their study, when methyl methylacrylate was used as both reagent and solvent (90 equiv.), the corresponding yield reached at least $74 \%$ depending on the alcohol. Under these considerations, we decided to adopt a similar strategy with the exceptions that the temperature was increased and the amount of lipase was lowered to $10 \mathrm{w} \%$ to reduce the cost of the process (Scheme 3).

Table 2. Esterification of $\mathrm{HBO}$ in HBO-m in presence of CAL-B. ${ }^{a}$

\begin{tabular}{lllll}
\hline Entry & MMA (eq.) & $\left.\mathrm{T}^{\circ} \mathrm{C}\right)$ & Conv. $\left.^{\circ} \%\right)^{\mathrm{a}}$ & Yield $^{\mathrm{b}}(\%)$ \\
\hline 1 & 25 & 50 & 46 & 38 \\
2 & 25 & 70 & 70 & 64 \\
3 & 25 & 80 & 24 & 22 \\
4 & 100 & 70 & 69 & 64
\end{tabular}

aConditions: 10 w\% of CAL-B, 1 day. ${ }^{a}$ Estimated by ${ }^{1} \mathrm{H}$ NMR in $\mathrm{CDCl}_{3} .{ }^{\mathrm{b}}$ Yield obtained after purification.

Table 2, Entry 1 shows that at $50^{\circ} \mathrm{C}$ the chemo-enzymatic esterification of MMA with HBO does occur with a moderate conversion of $46 \%$. With a boiling point of $101^{\circ} \mathrm{C}$, excess MMA was easily removed during concentration whereas HBO was separated from the product by washing the organic layer with deionized water. The resulting unreacted starting materials can be reengaged in a reaction after isolation. Finally, the crude material was subjected to quick filtration over silica gel. 


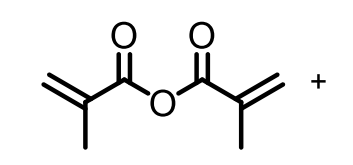

methacrylic anhydride
$\mathrm{HO}_{\mathrm{H}}^{\mathrm{H}}=\mathrm{O}$

HBO

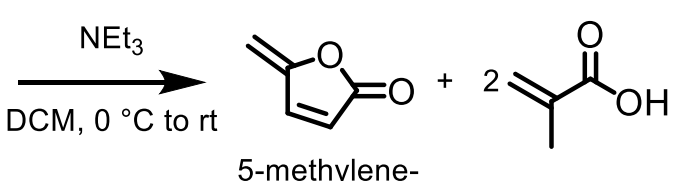

5-methylene$2(5 H)$-furanone

Scheme 4. Methacrylation of HBO resulting in the formation of 5-methylene-2(5H)furanone.

Because of the high stability of Novozyme 435, higher temperatures were investigated and the optimal conditions were obtained at $70^{\circ} \mathrm{C}$. It is worth noting that at $80^{\circ} \mathrm{C}$ (Table 2, Entry 3), a substantial drop of the conversion corresponding to a lower activity of the enzyme was observed, probably because of CAL-B unfolding or degradation. A larger amount of MMA (100 equiv., Table 2, Entry 4) was investigated but similar yields were obtained versus 25 equiv. of MMA. The hydrogenated version of HBO, $2 \mathrm{H}-\mathrm{HBO}$, was then submitted to the same conditions and gave a good yield (62\%). Subsequent polymerizations were attempted either without further purification or after silica gel chromatography column and no notable differences were observed. It is worth noting that methacrylation of $\mathrm{HBO}$ was also attempted with methacrylic anhydride in the presence of a base. However, degradation of the desired product into 5-methylene-2(5H)furanone (Scheme 4) was observed at room temperature. Indeed, 5 minutes after addition of the methacrylation reagent, the targeted molecule was observed but an hour later only traces of HBO-m remained. The reaction was also maintained at $0{ }^{\circ} \mathrm{C}$ and stopped 10 minutes after addition. The product was isolated after purification over silica gel chromatography with a lower yield than the chemo-enzymatic method.

With the monomers in hand, free radical homopolymerization of $\mathbf{2 H}-\mathbf{H B O}-\mathbf{m}$ was studied in the presence of azo initiators (i.e., AIBN, V-65, and V-70). V-65 allowed a conversion of $43 \%$ into poly $(2 \mathrm{H}-\mathrm{HBO}-\mathrm{m})$ whereas quantitative conversion was reached 
with AIBN (Table 3). During the polymerization, the polymers precipitated from the toluene solution. Moreover, they were not soluble in gel permeation chromatography (GPC) solvents THF or hexafluoroisopropanol (HFiP), which precluded both molecular weight and dispersity analysis. Glass transitions of the homopolymers were measured by differential scanning calorimetry (DSC) and ranged from 93 to $102^{\circ} \mathrm{C}$ (Table 3).

Table 3. Homopolymerization of $2 \mathrm{H}-\mathrm{HBO}-\mathrm{m}$ and polymer thermal data. ${ }^{\mathrm{a}}$

\begin{tabular}{lllll}
\hline Entry & Initiator & $\mathrm{T}\left({ }^{\circ} \mathrm{C}\right)$ & Yield $(\%)$ & $T_{\mathrm{g}}^{\mathrm{b}}\left({ }^{\circ} \mathrm{C}\right)$ \\
\hline 1 & AlBN & 75 & quantitative & 98 \\
2 & V-65 & 55 & 43 & 93 \\
3 & V-70 & 35 & 37 & 102
\end{tabular}

aConditions: $1 \overline{\mathrm{M}}$ of monomer in toluene; 1 mol\% initiator; 90 minutes. ${ }^{\mathrm{b}}$ Determined by DSC under $\mathrm{N}_{2}$.

Homopolymerization of HBO-m (Scheme 5) was also attempted with the same conditions described above; no polymer precipitated from toluene during the process but the solution turned yellow. Addition of hexane to the resulting solution did not provide any solid after 1.5 hours, but an insoluble and yellow layer formed at the bottom of the beaker. The separated material was assumed to be oligomers since HBO-m is fully soluble in conventional organic solvents such as hexane. However, subsequent ${ }^{1} \mathrm{H}$ NMR analysis mainly showed monomer peaks. Homopolymerizations with longer reaction times $(3,6$, 12 , and 24h) were attempted but no significant changes were observed. In order to evaluate the reactivity of the unsaturated lactone, HBO acetate was synthetized from ethyl acetate (25 equiv.) and HBO (1 equiv.) in the presence of CAL-B (10 w\%), and was then subjected to free radical polymerization conditions. After $1.5 \mathrm{~h}$ the resulting yellow 
solution was combined with hexane; no material precipitated, but the solution became somewhat cloudy. Finally, copolymerization of HBO acetate and 2H-HBO-m was attempted but did not provide any polymer.

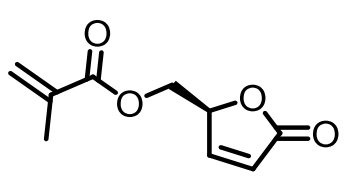

HBO-m
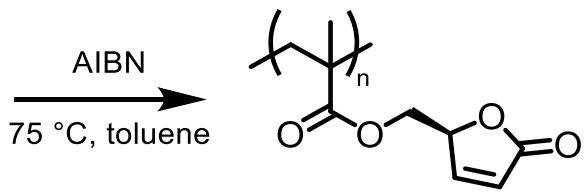

poly(HBO-m)

Scheme 5. Homopolymerization of HBO-m.

Consequently, the $\alpha, \beta$-unsaturated lactone was suspected to hinder the acrylate polymerization. Note that, after a few weeks, the stock of HBO-m solidified to a yellow and insoluble material that did not exhibit any $T_{\mathrm{g}}$ during DSC analysis (See Figure S107 in the ESI). Copolymerization with hydrogen-bonding monomers can increase $T_{\mathrm{g}}$ values and/or improve solubility. Thus, the copolymerization of $\mathbf{2 H}-\mathrm{HBO}-\mathbf{m}$ with methacrylamide (MAA) was pursued. Because of its insolubility in toluene, dimethyl formamide (DMF) was employed as the polymerization solvent. Table 4 describes the copolymerization of 2H-HBO-m and MMA with different feed fractions. As previously discussed, poly $(2 \mathrm{H}-$ HBO-m) tends to precipitate during its homopolymerization, and this trend was also observed for the copolymerization with MAA. We assumed that $\mathbf{2 H}-\mathbf{H B O}-\mathbf{m}$ is more reactive than MAA; ${ }^{21}$ hence, the faster incorporation of $\mathbf{2 H}-\mathbf{H B O}-\mathbf{m}$ causes the polymer to precipitate when high molecular weights are achieved. It is worth noting that for a high MMA loading (Entries $8 \& 9$ ), the feed fraction and the incorporation fraction are similar. Plausibly, the smaller amount of $\mathbf{2 H}-\mathbf{H B O}-\mathbf{m}$ in the polymer chain compared to MAA is not high enough to effect precipitation of the material before substantial incorporation of 
Table 4. Incorporation, molecular weight, and thermal data for poly(2H-HBO-m-comethacrylamide).

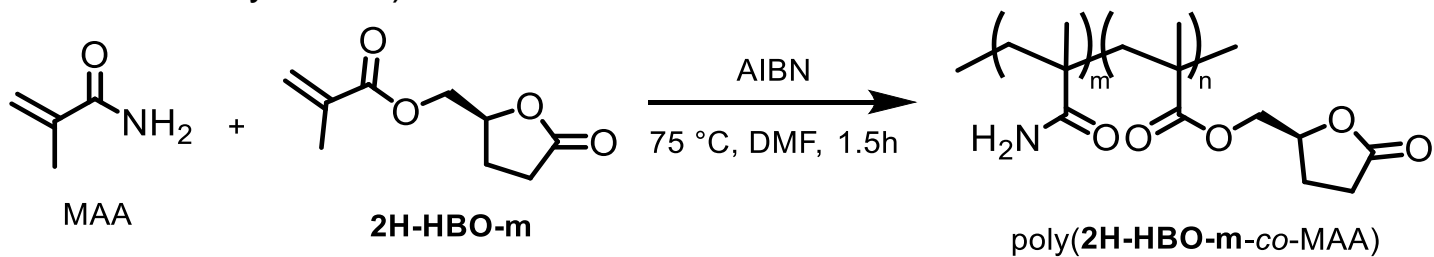

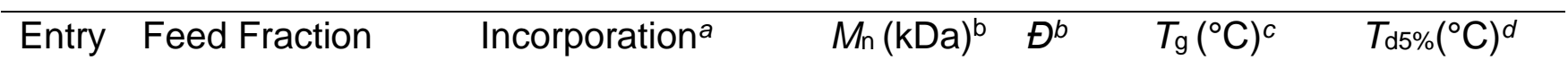

2H-HBO-m / MAA 2H-HBO-m / MAA

\begin{tabular}{lllllll}
\hline 1 & $90 / 10$ & $100 /$ trace & 23.5 & 2.2 & 94 & 228 \\
\hline 2 & $80 / 20$ & $98 / 2$ & 20.7 & 2.3 & 115 & 217 \\
3 & $70 / 30$ & $78 / 22$ & 28.7 & 2.1 & 128 & 198 \\
4 & $60 / 40$ & $76 / 24$ & 19.2 & 2.0 & 143 & 261 \\
5 & $50 / 50$ & $70 / 30$ & 21.1 & 2.3 & 144 & 189 \\
6 & $40 / 60$ & $74 / 26$ & 17.9 & 1.7 & 141 & 237 \\
7 & $30 / 70$ & $54 / 46$ & 19.4 & 1.7 & 152 & 237 \\
8 & $20 / 80$ & $28 / 72$ & 18.1 & 1.8 & 172 & 241 \\
9 & $10 / 90$ & $11 / 89$ & 12.1 & 2.2 & 187 & 124 \\
\hline
\end{tabular}

alncorporation was measured by ${ }^{1} \mathrm{H}$ NMR in $\mathrm{CDCl}_{3} .{ }^{b} \mathrm{GPC}$ in hexafluoroisopropanol (HFiP) at $40{ }^{\circ} \mathrm{C}$ vs. polymethyl methacrylate standards ${ }^{\circ}$ Determined by DSC under $\mathrm{N}_{2}$. ${ }^{\mathrm{O}} \mathrm{TGA}$ temperature at which $5 \%$ mass loss was observed under nitrogen.

MAA. However, Entry 1 in Table 4 demonstrates that even traces of incorporated MAA are sufficient to make the polymer soluble in HFiP, probably because of amide hydrogen bonding with this solvent. High molecular weights between 12 and 29 kDa (Entries 9 \& 3) were reached with typical dispersities ranging between 1.7 and 2.3 (Entries 6 \& 2). Polymers were then submitted to DSC analysis. Table 4 summarizes glass transition temperatures and reveals a correlation between $T_{\mathrm{g}}$ and the MAA incorporation, as 
measured by ${ }^{1} \mathrm{H}$ NMR (Figure 1). For example, the small feed fraction of $10 \%$ MAA allowed only traces of incorporated MAA and the corresponding $T_{\mathrm{g}}$ of $94{ }^{\circ} \mathrm{C}$ aligns with that of poly $(2 \mathrm{H}-\mathrm{HBO}-\mathrm{m})$ itself $\left(93-102^{\circ} \mathrm{C}\right)$. Entries 4 \& 6 show intermediate MAA incorporations of 24 and $26 \%$ with similar $T_{g}$ values of 143 and 141 . The highest incorporations of MAA (72 or $89 \%$ ) resulted in the highest $T_{\mathrm{g}}$ values (172 and $187^{\circ} \mathrm{C}$ ). Methylene- $y$-valerolactone (MGVL) was then considered as a comonomer because it is biobased and conformationally rigid, a property that predictably imparts high $T_{\mathrm{g}}$ values. Its precursor, $\mathrm{y}$-valerolactone (GVL), is easily produced from biobased levulinic acid (LA) through carbonyl reduction followed by ring closing. ${ }^{22,23}$

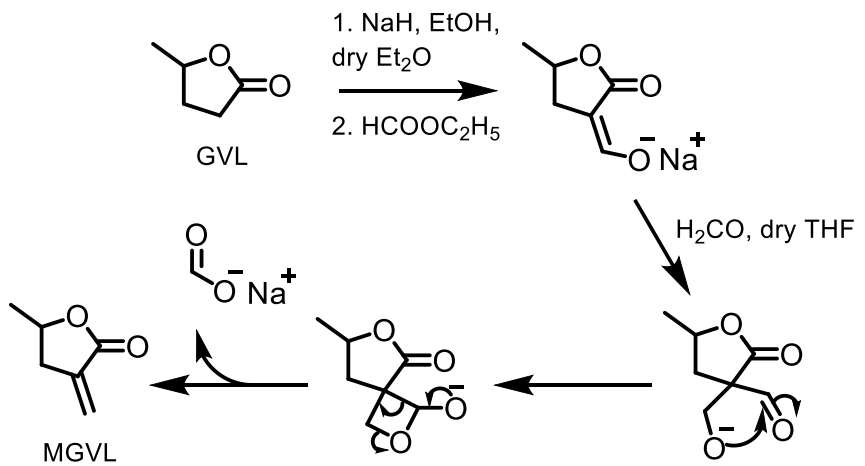

Scheme 6. $\alpha$-methylenation of $\gamma$-valerolactone (GVL) to yield methylene- $\gamma$-valerolactone (MGVL).

Then a-methylenation can be performed in two steps, yielding MGVL. Scheme 6 describes one strategy used to synthetized MGVL from GVL. ${ }^{24}$ The synthesis starts with a-deprotonation of the lactone; the resulting enolate then attacks ethyl formate to form a salt which is isolated by filtration. A catalytic amount of ethanol substantially decreases the reaction time..$^{25}$ 
Table 5. Incorporation, molecular weight, and thermal data for poly(2H-HBO-m-coMGVL).

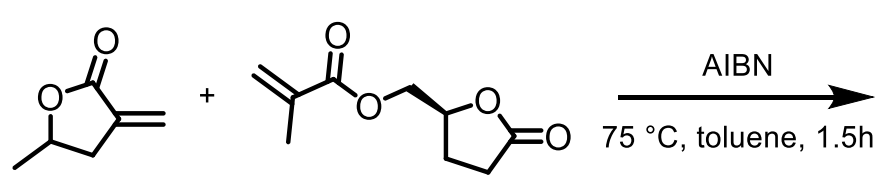

MGVL

2H-HBO-m

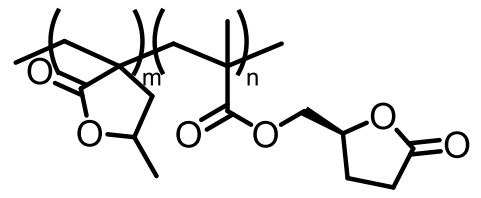

poly(2H-HBO-m-co-MGVL)

\begin{tabular}{|c|c|c|c|c|c|c|}
\hline Entry & $\begin{array}{c}\text { Feed Fractions } \\
\text { 2H-HBO-m / MGVL }\end{array}$ & $\begin{array}{c}\text { Incorporation }^{\mathrm{a}} \\
\text { 2H-HBO-m / MGVL }\end{array}$ & $M_{\mathrm{n}}(\mathrm{kDa})^{\mathrm{b}}$ & $\oplus^{\mathrm{b}}$ & $\begin{array}{c}T_{\mathrm{g}} \\
\left({ }^{\circ} \mathrm{C}\right)^{\mathrm{C}}\end{array}$ & $\begin{array}{l}T_{\mathrm{d} 5 \%} \\
\left({ }^{\circ} \mathrm{C}\right)^{d}\end{array}$ \\
\hline 1 & $90 / 10$ & $88 / 12$ & insoluble & insoluble & 114 & 212 \\
\hline 2 & $80 / 20$ & $83 / 17$ & insoluble & insoluble & 122 & 273 \\
\hline 3 & $70 / 30$ & $70 / 30$ & insoluble & insoluble & 133 & 307 \\
\hline 4 & $60 / 40$ & $60 / 40$ & insoluble & insoluble & 147 & 332 \\
\hline 5 & $50 / 50$ & $49 / 51$ & insoluble & insoluble & 143 & 249 \\
\hline 6 & $40 / 60$ & $36 / 64$ & insoluble & insoluble & 158 & 340 \\
\hline 7 & $30 / 70$ & $28 / 72$ & insoluble & insoluble & 153 & 162 \\
\hline 8 & $20 / 80$ & $21 / 79$ & insoluble & insoluble & 178 & 170 \\
\hline 9 & $10 / 90$ & $18 / 82$ & 38.4 & 4.3 & 179 & 186 \\
\hline 10 & $0 / 100$ & $0 / 100$ & 22.9 & 2.3 & 200 & 342 \\
\hline
\end{tabular}

alncorporation was measured by $1 \mathrm{H} \mathrm{NMR} \mathrm{in} \mathrm{CDCl3} \mathrm{(S140).}{ }^{\mathrm{b}} \mathrm{GPC}$ in hexafluoro-2-propanol (HFiP) at 40 ${ }^{\circ} \mathrm{C}$ vs poly (methyl methacrylate) standards. "Determined by DSC under N2. ${ }^{\mathrm{d} T G A}$ temperature at which $5 \%$ mass loss was observed under nitrogen.

Apart from its biobased nature, MGVL offers a reactivity advantage because its cis conformation and planar structure do not hinder the approaching monomer during polymerization. Finally, vinyl-type polymers with MGVL generally exhibit high glass transition temperatures because of high conformational barriers associated with the 
persistent lactone rings. ${ }^{24}$ Table 5 summarizes the copolymerization between $\mathbf{2 H - H B O}$ m and MGVL. Unfortunately, most of the resulting polymers were insoluble in the GPC solvents THF and HFiP. Note that an incorporation of $82 \%$ of MGVL results in a soluble polymer $\left(\mathrm{CDCl}_{3}\right)$ with a high $M_{\mathrm{n}}$ of $38.4 \mathrm{kDa}$ (Entry 9$)$ but with slightly less incorporated MGVL (79\%), the polymer is insoluble. Note that copolymerizations with MGVL and $\mathbf{2} \mathbf{H}-$ HBO-m gave incorporation fractions rather well matched to the feed fractions compared

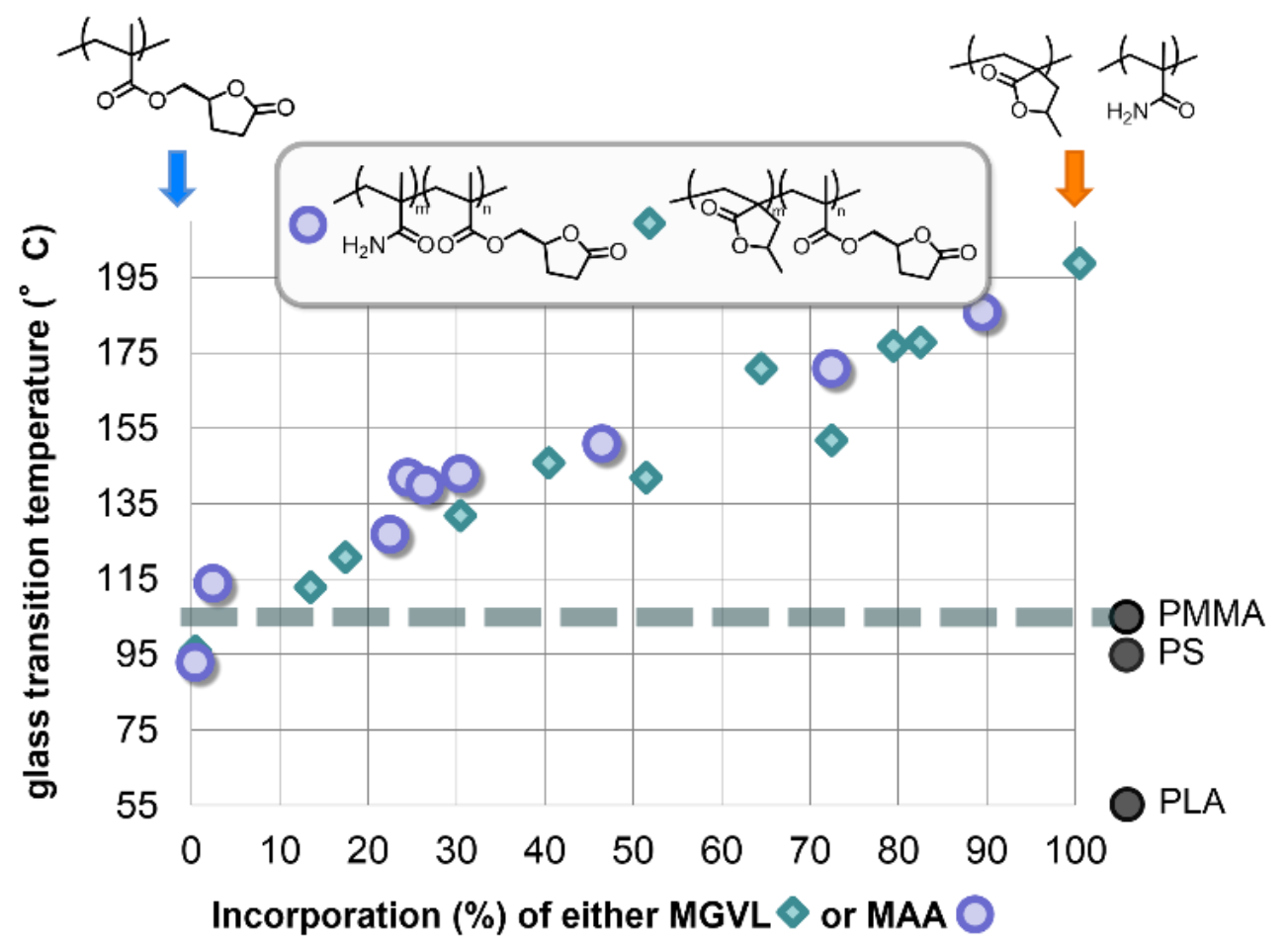

Figure 1. Polymer $T_{\mathrm{g}}$ values vs. MMA or MGVL comonomer incorporation compared to commodity plastics: PMMA $\left(105^{\circ} \mathrm{C}\right)$, PS $\left(95^{\circ} \mathrm{C}\right)$, and PLA $\left(55^{\circ} \mathrm{C}\right)$.

to copolymerizations between MAA and $\mathbf{2 H - H B O - m}$. For instance, Entries 3, 4, and 5 (Table 5) describe matching values between feed fractions and incorporations and Entry 8 only deviates by $1 \%$, all within the error of the measurement. As expected, $T_{\mathrm{g}}$ values of the copolymers are substantially influenced by the content of MGVL in the backbone. 
Higher fractions of MGVL afford higher glass transition temperatures (Figure 1). Table 5, Entry 1 shows that just $13 \%$ MGVL lactone in the final polymer increases the $T_{\mathrm{g}}$ to 114 ${ }^{\circ} \mathrm{C}$ from the value $98^{\circ} \mathrm{C}$ for the $\mathbf{2 H}-\mathbf{H B O}-\mathbf{m}$ homopolymer of Table 3 , Entry 1. A substantially higher $T_{\mathrm{g}}$ of $150{ }^{\circ} \mathrm{C}$ is observed for $51 \% \mathrm{MGVL}$ (Table 5 , Entry 5 ) and a $T_{\mathrm{g}}$ of $179^{\circ} \mathrm{C}$ is observed for $82 \%$ MGVL (Table 5, Entry 9). The spanned $T_{g}$ range for poly (2H-HBO-m-co-MGVL) $\left(98\right.$ to $\left.200^{\circ} \mathrm{C}\right)$ is similar to that of poly $(2 \mathrm{H}-\mathrm{HBO}-\mathrm{m}-\mathrm{co}-\mathrm{MAA})$ (98 to $\left.187^{\circ} \mathrm{C}\right)$.

Inspired by the aforementioned synthesis of MGVL (from GVL) and its ability to impart high $T_{\mathrm{g}}$ values, we targeted the methylenation of $\mathbf{2 H}$-HBO itself. However, for this target, protection of the hydroxyl group was essential since the methods employed use strong bases, likely to form an alkoxide that might open the lactone.

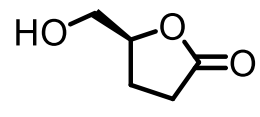

2H-HBO

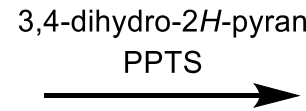

DMC, rt, $\mathrm{N}_{2}$

. $\mathrm{NaH}, \mathrm{EtOH}$, dry $\mathrm{Et}_{2} \mathrm{O}$

2. $\mathrm{HCOOC}_{2} \mathrm{H}_{5}$

3. paraformaldehyde, THF, reflux

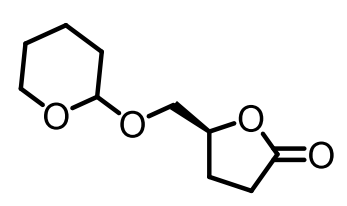

THP-2H-HBO

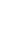


Table 6. Incorporation, molecular weight, and thermal data for poly(M-THP-2H-HBOco-methyl methacrylate).

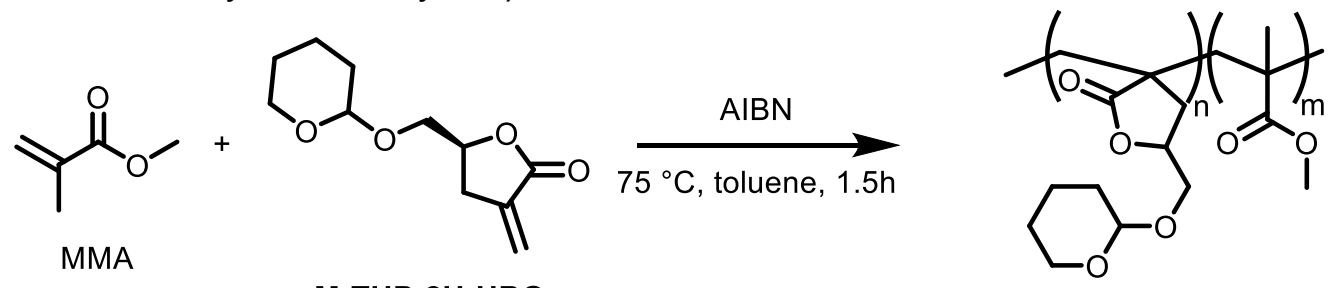

M-THP-2H-HBO

poly(M-THP-2H-HBO-co-MMA)

\begin{tabular}{ccccccc}
\hline Entry & $\begin{array}{c}\text { Feed fractions } \\
\text { M-THP-2H-HBO / MMA }\end{array}$ & $\begin{array}{c}\text { Incorporation }^{a} \\
\text { M-THP-2H-HBO / MMA }\end{array}$ & $\begin{array}{c}\mathrm{Mn}_{\mathrm{n}} \\
(\mathrm{kDa})^{b}\end{array}$ & $\begin{array}{c}T_{\mathrm{g}} \\
\left({ }^{\circ} \mathrm{C}\right)^{c}\end{array}$ & $\begin{array}{c}T_{\mathrm{d} 5 \%} \\
\left({ }^{\circ} \mathrm{C}\right)^{d}\end{array}$ \\
\hline 1 & $10 / 90$ & $10 / 90$ & 14.9 & 2.2 & 101 & 162 \\
\hline 2 & $20 / 80$ & $29 / 71$ & 14.2 & 2.3 & 109 & 195 \\
3 & $30 / 70$ & $41 / 59$ & 15.1 & 2.9 & 116 & 184 \\
\hline 4 & $39 / 61$ & $53 / 47$ & 22.0 & 2.4 & 124 & 192 \\
\hline 5 & $49 / 51$ & $56 / 44$ & 17.0 & 2.6 & 128 & 212 \\
\hline 6 & $60 / 40$ & $68 / 32$ & 23.0 & 2.7 & 140 & 198 \\
\hline 7 & $70 / 30$ & $72 / 28$ & 24.9 & 2.7 & 137 & 194 \\
\hline 8 & $80 / 20$ & $76 / 24$ & 27.1 & 3.2 & 140 & 189 \\
\hline 9 & $90 / 10$ & $85 / 15$ & 16.9 & 4.3 & 147 & 186 \\
\hline 10 & $100 / 0$ & $100 / 0$ & 44.4 & 2.2 & 148 & 188 \\
\hline
\end{tabular}

alncorporation was measured by ${ }^{1} \mathrm{H}$ NMR. ${ }^{b} \mathrm{GPC}$ in hexafluoroisopropanol (HFiP) at $40{ }^{\circ} \mathrm{C}$ vs. polymethyl methacrylate standards. ${ }^{c}$ Determined by DSC under $\mathrm{N}_{2}$. ${ }^{\circ} \mathrm{TGA}$ temperature at which $5 \%$ mass loss was observed under nitrogen.

HBO was observed; it tends to oligomerize slowly, but this did not preclude subsequent polymerization studies. Still, this reactivity discounted the option of removing the protecting group prior to polymerization. 
In order to compare poly(methyl methacrylate) (PMMA) and poly(M-THP-2HHBO), copolymerizations with varying feed fractions were conducted using AIBN as the initiator in toluene at $70{ }^{\circ} \mathrm{C}$ for $1.5 \mathrm{~h}$. The materials were then precipitated by addition of hexane. Table 6 shows the experiments with various monomer loadings from $10 \% \mathbf{M}$ THP-2H-HBO (Entry 1) to $100 \%$ (Entry 9). High $M$ values of $14.9 \mathrm{kDa}, 22.0 \mathrm{kDa}$, and $27.1 \mathrm{kDa}$ (Entries 1, 4, and 8), for example, are observed. Note that poly(M-THP-2HHBO) even reached an $M_{n}$ value of $44.4 \mathrm{kDa}$ with a nearly ideal dispersity of 2.2.

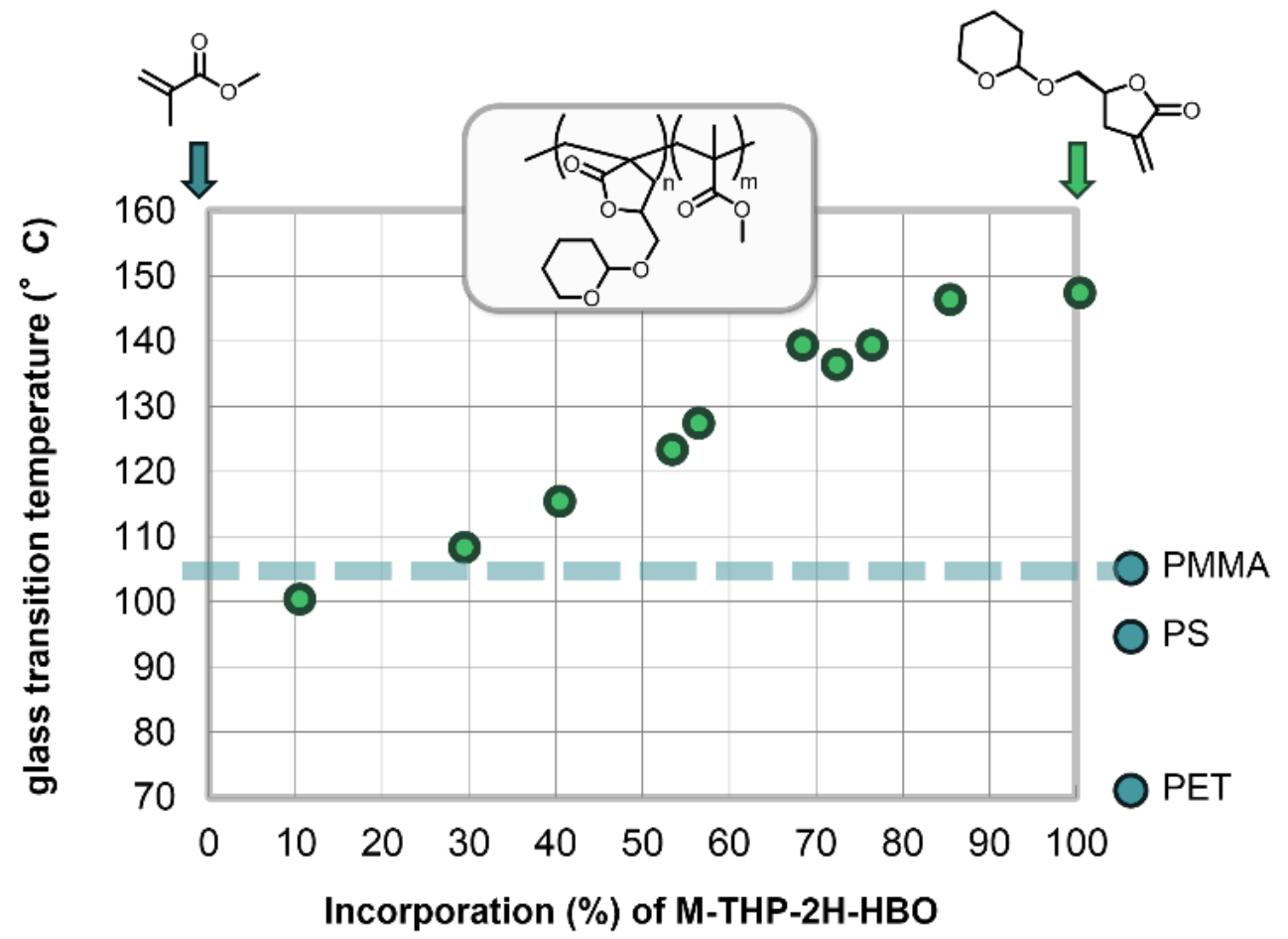

Figure 2. Copolymer $T_{\mathrm{g}}$ values vs. incorporation of M-THP-2H-HBO compared to commodity plastics: PMMA $\left(105^{\circ} \mathrm{C}\right)$, PS $\left(95^{\circ} \mathrm{C}\right)$, and PET $\left(72^{\circ} \mathrm{C}\right)$.

To focus on the thermal properties, the highest glass transition temperature of the series belongs to the homopolymer poly(M-THP-2H-HBO) at $148{ }^{\circ} \mathrm{C}$ (Table 6, Entry 10). At the lower end, the copolymer with just 10\% M-THP-2H-HBO incorporation (Table 6, 
Entry 1) has a $T_{g}$ of $101^{\circ} \mathrm{C}$. Polymers with a higher fraction of $\mathbf{M}-\mathrm{THP}-2 \mathrm{H}-\mathrm{HBO}$ exhibit proportionally higher $T_{\mathrm{g}}$ values, as illustrated in Figure 2. Figure 3 shows the thermal degradation analysis (TGA, under nitrogen) of poly(M-THP-2H-HBO) (Table 6, Entry 10) with a $T_{\mathrm{d} 5 \%}$ (5\% mass loss) around $188^{\circ} \mathrm{C}$; this is comparable to other $T_{\mathrm{d} 5 \%}$ values of the series. Note that the mass loss later reached a plateau at $246{ }^{\circ} \mathrm{C}(29 \%$ mass loss $)$ until $303{ }^{\circ} \mathrm{C}$ (34\% mass loss) and then degradation resumed thereafter. Plausibly, this degradation plateau represents the acetal deprotection /degradation as the THP moiety corresponds to $39.6 \%$ of the molecular weight of the monomer, when lost as dihydropyran. In attempt to verify this assumption, M-THP-2H-HBO was heated up to 240 ${ }^{\circ} \mathrm{C}$ for $5 \mathrm{~min}, 30 \mathrm{~min}$, or $90 \mathrm{~min}$. The insolubility of the resulting material prohibited any

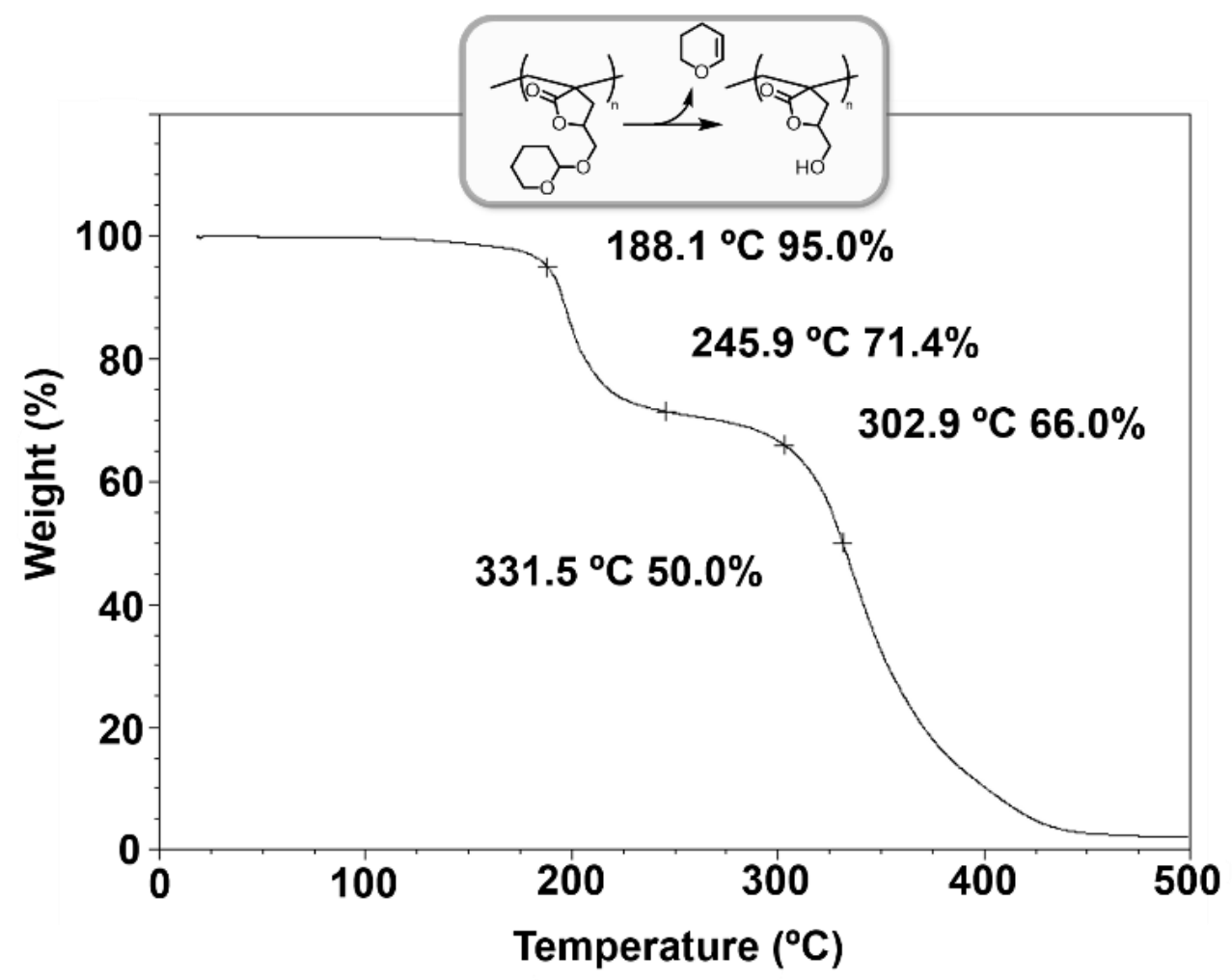

Figure 3. Thermal degradation of poly(M-THP-2H-HBO). The first plateau likely represents loss of the THP protecting group as dihydropyran, with about $29 \%$ mass lost. 
NMR analysis but IR spectroscopy showed a broad band around $3400-3500 \mathrm{~cm}^{-1}$ having an intensity that increased with time (Figure 4). This characteristic $\mathrm{OH}$ band is attributed to the alcohol functionality revealed upon loss of dihydropyran (Figure 3).

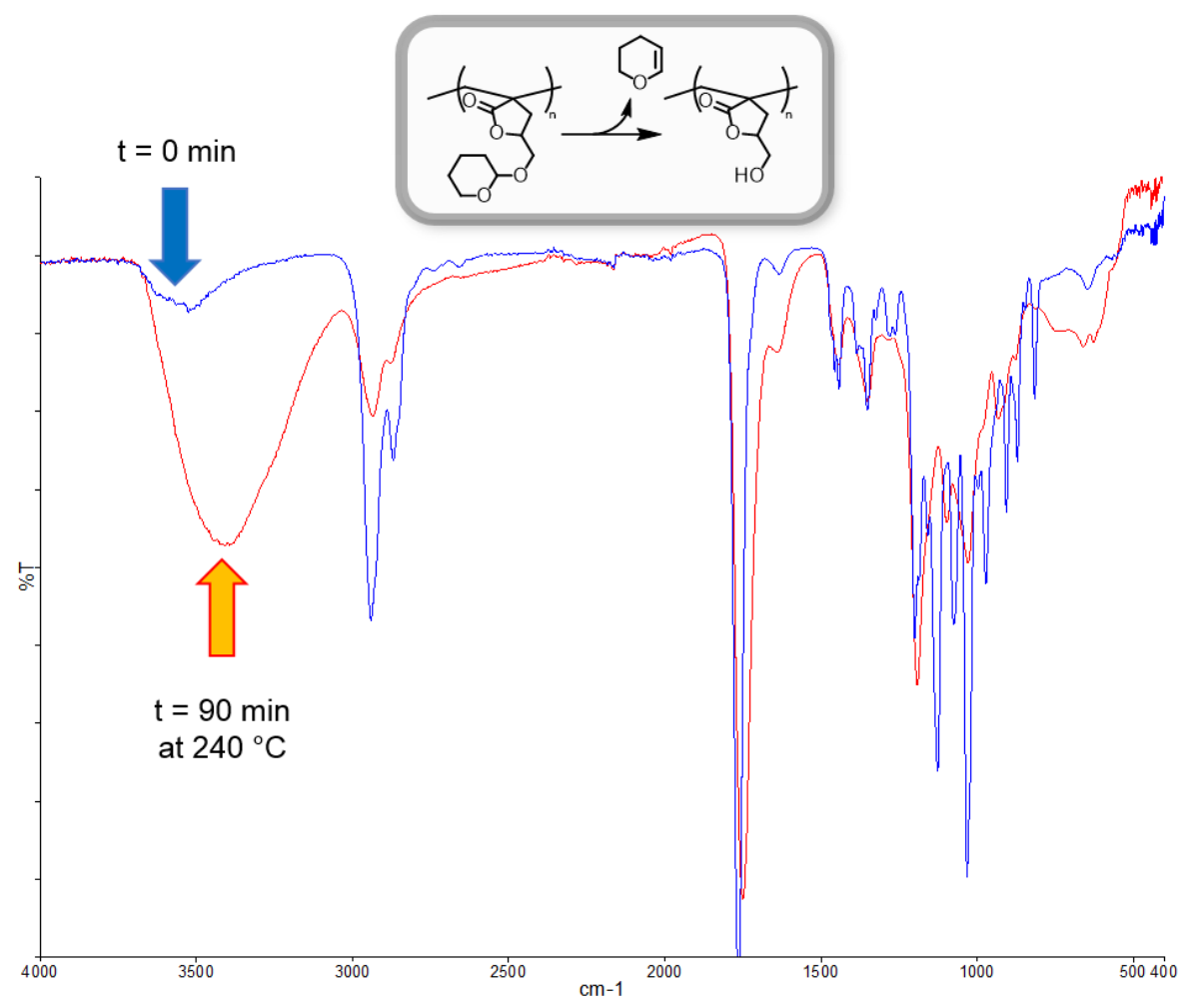

Figure 4. IR spectra of poly(M-THP-2H-HBO) before heating (blue) and after $90 \mathrm{~min}$ at $240{ }^{\circ} \mathrm{C}$ (red).

Note that there are two stereocenters in the repeat unit for poly(M-THP-2H-HBO): one attributed to the chiral $\mathbf{2 H}-\mathbf{H B O}$ monomer employed and one in the main chain created upon polymerization. Thus, this polymer possesses a tacticity that theoretically could be evaluated, potentially via ${ }^{13} \mathrm{C}$ NMR or ${ }^{1} \mathrm{H}$ NMR spectroscopy. However, the poor solubility of the material in conventional NMR solvents did not allow sufficient resolution of any diastereomeric peaks in the corresponding spectra. Our assumption is that the 
main chain tacticity is essentially atactic since stereoselectivity is invariably poor with this method of radical polymerization. The side chain chirality is also inconsequential as amorphous polymers - without melting temperatures - are observed with all the polymers reported here.

\section{Conclusion}

An efficient and sustainable methacrylation of the biobased lactone $\mathrm{HBO}$ and its hydrogenated analogue, $\mathbf{2 H - H B O}$, has been successfully achieved through a lipasemediated chemo-enzymatic process that avoids chloride reagents and scavenging bases, while decreasing the amount of generated waste. Methacrylated $2 \mathrm{H}-\mathrm{HBO}-\mathrm{m}$ was successfully polymerized through a free radical process, providing homopolymers with $T_{g}$ values near $98{ }^{\circ} \mathrm{C}$. The glass transition temperature was then increased via copolymerization of $\mathbf{2 H}-\mathbf{H B O}-\mathbf{m}$ with methacrylamide (MAA). An additional effect of this comonomer was to impart polymer solubility in organic solvents; even trace amounts of incorporated MMA allowed for solubility in the GPC solvent hexafluoroisopropanol (HFiP). A second copolymer series was created with $\mathbf{2 H}-\mathrm{HBO}-\mathbf{m}$ and methylene- $\mathrm{y}$-valerolactone (MGVL), a biobased, cyclic acrylate that is known to effect conformational inflexibility.

Whether by increasing hydrogen bonding (MAA comonomer) or by increasing conformational barriers (MGVL comonomer) high $T_{\mathrm{g}}$ ranges $\left(100^{\circ} \mathrm{C}\right.$ to $190{ }^{\circ} \mathrm{C}$ ) were observed with these two copolymer series from $2 \mathrm{H}-\mathrm{HBO}-\mathbf{m}$. Additionally, $2 \mathrm{H}-\mathrm{HBO}$ was subjected to hydroxy group protection (with dihydropyran) and a-methylenation to produce a new acrylate monomer, M-THP-2H-HBO, that was homopolymerized and then copolymerized with methyl methacrylate (MMA). The $T_{g}$ range of this copolymer series 
spans from 101 to $147^{\circ} \mathrm{C}$ and the homopolymer itself, poly(M-THP-2H-HBO), has a $T_{g}$ of $148^{\circ} \mathrm{C}$ and a high molecular weight of $44.4 \mathrm{kDa}$.

Levoglucosenone (LGO) and its oxidized derivative ( $S$ )-y-hydroxymethyl- $\alpha, \beta$-butenolide (HBO) have recently become available in useful quantities from various cellulosic biomass sources. ${ }^{26}$ The chemistry reported herein describes the efficient production of acrylate monomers from $\mathrm{HBO}$ and their polymerization to promising polymers and copolymers with tuneable properties-especially glass transition temperature values competitive with several high- $T_{\mathrm{g}}$ commodity plastics, including polyethylene terephthalate (PET), polystyrene (PS), polyvinyl chloride (PVC), polymethylmethacrylate (PMMA), and even polycarbonate (PC). Finally, these polymers have been designed for postpolymerization modifications, which will be reported in the future and will further expand their potential applications.

\section{Associated Content}

The Supporting Information is available free of charge on the editor website at DOI: 10.1021/acssuschemeng.8b04707. NMR spectra, DSC and TGA traces, IR traces, mass spectrometry spectra and calculations for copolymer incorporation ratios, photograph of material resulting from the "spontaneous" homopolymerization of HBO-m.

\section{Author Information}

Corresponding Authors

*S. A. Miller. E-mail: miller@chem.ufl.edu.

*F. Allais. E-mail: florent.allais@agroparistech.fr. 
ORCID: Florent Allais: 0000-0003-4132-6210

Notes: The authors declare no competing financial interest.

\section{Acknowledgments}

This research was supported by the National Science Foundation (CHE-1607263), NIH S10 OD021758-01A1 (Mass Spectrometer), and a joint collaboration between Chaire Agro-Biotechnologies Industrielles $(\mathrm{ABI})$ and the University of Florida. The authors are grateful to the Circa Group for providing industrial grade levoglucosenone. The authors are also grateful to Grand Reims, Département de la Marne, Grand Est and Fondation du Site Paris-Reims for financial support.

\section{References}

1. Geyer, R., Jambeck, J. R. \& Law, K. L. Production, use, and fate of all plastics ever made. Sci. Adv. 3, (2017).

2. Schneiderman, D. K. \& Hillmyer, M. A. 50th Anniversary Perspective: There Is a Great Future in Sustainable Polymers. Macromolecules 50, 3733-3749 (2017).

3. Wang, G., Jiang, M., Zhang, Q., Wang, R. \& Zhou, G. Biobased multiblock copolymers: Synthesis, properties and shape memory performance of poly(ethylene 2,5-furandicarboxylate)-b-poly(ethylene glycol). Polym. Degrad. Stab. 144, 121-127 (2017).

4. Espinach, F. X. et al. Composites from poly(lactic acid) and bleached chemical fibres: Thermal properties. Compos. Part B Eng. 134, 169-176 (2018).

5. Nguyen, H. T. H., Qi, P., Rostagno, M., Feteha, A. \& Miller, S. A. The quest for high glass transition temperature bioplastics. J. Mater. Chem. A 6, 9298-9331 (2018).

6. Qi, P., Chen, H. L., Nguyen, H. T. H., Lin, C. C. \& Miller, S. A. Synthesis of biorenewable and water-degradable polylactam esters from itaconic acid. Green Chem. 18, 4170-4175 (2016). 
7. Werpy, T. \& Petersen, G. Top Value Added Chemicals from Biomass Volume I. U.S. Dep. energy 1, 1-76 (2004).

8. Leal Silva, J. F., Grekin, R., Mariano, A. P. \& Maciel Filho, R. Making Levulinic Acid and Ethyl Levulinate Economically Viable: A Worldwide Technoeconomic and Environmental Assessment of Possible Routes. Energy Technol. 6, 613-639 (2018).

9. Della Pina, C., Falletta, E. \& Rossi, M. A green approach to chemical building blocks. the case of 3-hydroxypropanoic acid. Green Chem. 13, 1624-1632 (2011).

10. R., G. et al. Method for converting lignocellulosic materials into useful chemicals. (2016).

11. Flourat, A. L., Peru, A. A. M., Teixeira, A. R. S., Brunissen, F. \& Allais, F. Chemoenzymatic synthesis of key intermediates (S)- $\gamma$-hydroxymethyl- $\alpha, \beta$-butenolide and (S)- $y$-hydroxymethyl- $y$-butyrolactone via lipase-mediated Baeyer-Villiger oxidation of levoglucosenone. Green Chem. 17, 404-412 (2015).

12. Bonneau, G., Peru, A. A. M., Flourat, A. L. \& Allais, F. Organic solvent- and catalyst-free Baeyer-Villiger oxidation of levoglucosenone and dihydrolevoglucosenone (Cyrene $\AA$ ): A sustainable route to (: $S)$ - $\gamma$-hydroxymethyl$\alpha, \beta$-butenolide and (S)- $\gamma$-hydroxymethyl- $\gamma$-butyrolactone. Green Chem. 20, 24552458 (2018).

13. Peru, A. A. M. et al. Chemo-enzymatic synthesis of chiral epoxides ethyl and methyl (S)-3-(Oxiran-2-yl)propanoates from Renewable levoglucosenone: An access to enantiopure (S)-dairy lactone. Molecules 21, 1-10 (2016).

14. Zamzow, M. \& Höcker, H. Synthesis of polymers with pendant spiro orthoester groups. Macromol. Chem. Phys. 195, 2381-2400 (1994).

15. Ray, P., Hughes, T., Smith, C., Simon, G. P. \& Saito, K. Synthesis of Bioacrylic Polymers from Dihydro-5-hydroxyl furan-2-one (2H-HBO) by Free and Controlled Radical Polymerization. ACS Omega 3, 2040-2048 (2018).

16. Prat, D. et al. CHEM21 selection guide of classical- and less classical-solvents. Green Chem. 18, 288-296 (2016).

17. Diot-Néant, F. et al. Biocatalytic synthesis and polymerization via ROMP of new biobased phenolic monomers: A Greener process toward sustainable antioxidant polymers. Front. Chem. 5, (2017).

18. Pion, F., Reano, A. F., Ducrot, P. H. \& Allais, F. Chemo-enzymatic preparation of new bio-based bis- and trisphenols: New versatile building blocks for polymer chemistry. RSC Adv. 3, 8988-8997 (2013). 
19. Sheldon, R. A. \& van Pelt, S. Enzyme immobilisation in biocatalysis: Why, what and how. Chem. Soc. Rev. 42, 6223-6235 (2013).

20. Warwel, S., Steinke, G. \& Klaas, M. R. G. An efficient method for lipase-catalysed preparation of acrylic and methacrylic acid esters. Biotechnol. Tech. 10, 283-286 (1996).

21. Kuo, S. W., Kao, H. C. \& Chang, F. C. Thermal behavior and specific interaction in high glass transition temperature PMMA copolymer. Polymer (Guildf). 44, 6873-6882 (2003).

22. Esposito, D. \& Antonietti, M. Redefining biorefinery: the search for unconventional building blocks for materials. Chem. Soc. Rev. 44, 5821-5835 (2015).

23. Alonso, D. M., Wettstein, S. G. \& Dumesic, J. A. Gamma-valerolactone, a sustainable platform molecule derived from lignocellulosic biomass. Green Chem. 15, 584-595 (2013).

24. Murray, A.W., Reid, R. . Convenient Synthesis of alpha-Epoxylactones (4-Oxo1,5-dioxaspiro[2.4]heptanes and - [2.5]octanes). Synthesis (Stuttg). 16, 35-38 (1985).

25. Barbier, P. \& Benezra, C. Allergenic a-Methylene-y-butyrolactones. Stereospecific Syntheses of ( + )- and (-)-y-Methyl-a-methylene-y-butyrolactonesA. Study of the Specificity of $(+)$ and (-) Enantiomers in Inducing Allergic Contact Dermatitis. J. Med. Chem. 25, 943-946 (1982).

26. Teixeira, A. R. S., Flourat, A. L., Peru, A. A. M., Brunissen, F. \& Allais, F. Lipasecatalyzed baeyer-villiger oxidation of cellulose-derived levoglucosenone into (S)$\gamma$-hydroxymethyl- $\alpha, \beta$-butenolide: Optimization by response surface methodology. Front. Chem. 4, 1-11 (2016). 